Review

\title{
Preparation and Application of Biochar-Based Catalysts for Biofuel Production
}

\author{
Feng Cheng (iD) and Xiuwei Li * \\ School of Energy and Power Engineering, Nanjing University of Science and Technology, Nanjing 210094, China; \\ fengcheng@njust.edu.cn \\ * Correspondence: good3000best@163.com; Tel.: +86-25-8431-7344
}

Received: 19 July 2018; Accepted: 17 August 2018; Published: 24 August 2018

\begin{abstract}
Firstly, this paper reviews two main methods for biochar synthesis, namely conventional pyrolysis and hydrothermal carbonization (HTC). The related processes are described, and the influences of biomass nature and reaction conditions, especially temperature, are discussed. Compared to pyrolysis, HTC has advantages for processing high-moisture biomass and producing spherical biochar particles. Secondly, typical features of biochar in comparison with other carbonaceous materials are summarized. They refer to the presence of inorganics, surface functional groups, and local crystalline structures made up of highly conjugated aromatic sheets. Thirdly, various strategies for biochar modification are illustrated. They include activation, surface functionalization, in situ heteroatom doping, and the formation of composites with other materials. An appropriate modification is necessary for biochar used as a catalyst. Fourthly, the applications of biochar-based catalysts in three important processes of biofuel production are reviewed. Sulfonated biochar shows good catalytic performance for biomass hydrolysis and biodiesel production. Biodiesel production can also be catalyzed by biochar-derived or -supported solid-alkali catalysts. Biochar alone and biochar-supported metals are potential catalysts for tar reduction during or after biomass gasification. Lastly, the merits of biochar-based catalysts are summarized. Biochar-based catalysts have great developmental prospects. Future work needs to focus on the study of mechanism and process design.
\end{abstract}

Keywords: heterogeneous catalysis; biorefinery; solid-acid catalyst; biochar-supported metal catalysts; surface functional groups; hydrothermal carbonization; surface functionalization; biofuel production

\section{Introduction}

The limited reserves of fossil fuels on Earth and the environmental problems associated with their use drive people to turn to renewable alternatives such as solar energy, wind energy, and biomass energy. Biomass is the most ancient fuel, providing light and heat to human beings for centuries. However, the traditional combustion of biomass is gradually being abandoned due to its low energy efficiency and air pollution. On the other hand, biomass-derived liquid or gaseous fuels are more adaptable to modern society. Hence, extensive studies are devoted to the production of biofuels. Currently, the primary conversion technologies include (1) biomass fermentation to produce bio-ethanol, (2) transesterification of vegetable oil or fat with alcohols to produce bio-diesel, (3) biomass gasification to produce syngas, and (4) fast pyrolysis of biomass to produce bio-oil, as Figure 1 displays. 


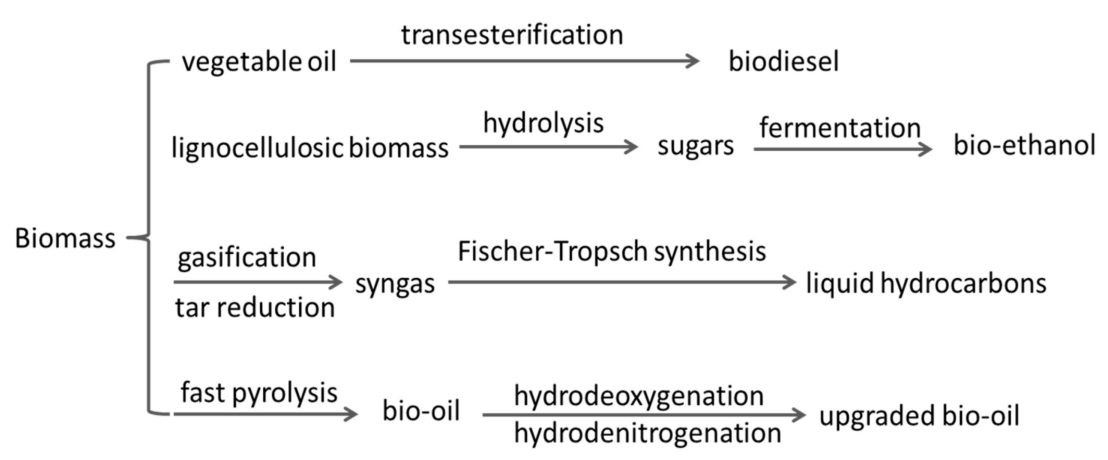

Figure 1. Primary conversion pathways from biomass to biofuel.

Catalysis, especially heterogeneous catalysis, plays an important role in biofuel production [1]. For instance, the conversion efficiency of vegetable oil to bio-diesel could be significantly enhanced using acid or alkali catalysts [2]. Tar reduction, which is crucial to the production of clean syngas via biomass gasification, also heavily relies on the use of catalysts [3]. Bio-oil cannot be directly utilized as transport fuel due to its poor fuel properties, e.g., high oxygen content and low higher heating value (HHV). The catalytic upgrading of bio-oil is considered as a promising route to overcome these shortcomings [4]. Similarly, the effective catalytic hydrolysis of cellulose to saccharides is the key to applying lignocellulosic biomass instead of cereals (e.g., corn, wheat) for bio-ethanol production [5].

Biochar is a type of carbonaceous materials obtained from the thermochemical conversion of biomass in an oxygen-limited environment [6]. Compared with conventional carbon materials such as carbon black and activated carbon from coal coke, biochar has several merits. Firstly, its feedstock is renewable, and its preparation process is simple. Biochar can be obtained as the main product of biomass carbonization, or as a by-product of biomass gasification and fast pyrolysis. Emerging techniques such as microwave pyrolysis [7,8] and hydrothermal carbonization [9] bring the production of biochar with more superiorities. Secondly, the physicochemical properties of biochar can be facilely tailored according to its specific application. A series of biochar modification strategies were developed to functionalize biochar. Because of these advantages, biochar has great potential to be used in the fields of heterogeneous catalysis, energy storage, pollution control, etc. The performances of biochar as soil amendment, carbon sequestration agents, contaminant adsorbents, electrode materials, catalysts, or catalyst supports were comprehensively reviewed in References $[6,10]$.

The potential of biochar as a catalyst or a catalyst support was extensively studied [11]. On one hand, some features of biochar benefit its role as a catalyst material. For instance, the presence of inorganics such as $\mathrm{K}$ and $\mathrm{Fe}$ in biochar contributes to its catalytic activity for tar cracking [12]. The surface functional groups of biochar could facilitate the adsorption of metal precursors, a necessary step for the synthesis of biochar-supported metal catalysts $[9,13,14]$. On the other hand, some characteristics of biochar, such as a low surface area and a poor porosity, hamper its catalytic application. Thus, various modification strategies were developed to endow biochar with specific properties. These strategies include selecting proper feedstock, controlling synthesis conditions, physical or chemical activation [10,13], surface functionalization [14,15], forming composites with other materials [16], etc. Comprehensive reviews on this topic can be found in References [15-17].

The processes for which biochar-based catalysts were tested include biomass refining $[13,14,18]$, $\mathrm{NO}_{\mathrm{x}}$ removal $[19,20]$, ammonia ozonation [21], electrocatalytic oxygen reduction and methanol oxidation in fuel cells [22,23], photocatalytic degradation of organics [24,25], nitrate degradation in wastewater [26], etc. A good review on the application of biochar-based catalysts was provided by Lee et al. [11] and Xiong et al. [14]. Biomass refining, which mimics petroleum refining, intends to produce valuable chemicals, fuels, and functional materials from biomass. Biochar-based catalysts are used in various biomass refining processes, such as biomass hydrolysis and dehydration [13,14], biodiesel production [2,27], biomass pyrolysis [28], bio-oil upgrading [4,28], tar removal [29,30], and the 
Fischer-Tropsch synthesis of liquid hydrocarbons from syngas [31], etc. Detailed information can be found in related reviews $[6,13,14]$. The application of biochar-based catalysts in biomass refining represents a more sustainable and more integrated process. This is because biochar is a common byproduct of biomass refinery, and the use of it can reduce the reliance of biomass refinery on metal catalysts or fossil-fuel-derived carbon catalysts.

The present review summarizes the preparation, modification, and catalytic application of biochar in three important aspects of biofuel production, namely biomass hydrolysis, biodiesel production, and tar reduction. The link between biochar properties and synthesis conditions, and the link between catalytic performance and the physicochemical properties of biochar are focused on. The objective of this review is to provide some useful information for researchers to accomplish the purpose-driven synthesis of biochar-based catalysts.

\section{Synthesis of Biochar}

\subsection{Conventional Pyrolysis}

\subsubsection{Process Description}

In general, biochar can be produced on various pyrolysis platforms, such as slow pyrolysis, fast pyrolysis, and pyrolytic gasification. Typical operating conditions and biochar yields of these pyrolysis platforms can be found in the literature $[6,10,15,32]$. The slow pyrolysis of biomass (also termed "biomass carbonization") is an ancient technology for biochar production. It is normally performed over a temperature range of $300-800{ }^{\circ} \mathrm{C}$ with a heating rate of $5-7^{\circ} \mathrm{C} / \mathrm{min}$ and a residence time of $>1 \mathrm{~h}$ [15]. The low heating rate and the long residence time favor a secondary cracking of vapors, and thus, lead to a high yield of biochar (30-50 wt \%). In comparison, a high heating rate and a short residence time in fast pyrolysis are beneficial for the production of bio-oil, with only small amounts of biochar (around $15 \mathrm{wt} \%$ ) being generated. Biochar is also a by-product $(10 \mathrm{wt} \%$ ) of biomass gasification which is mainly for syngas generation at $>750{ }^{\circ} \mathrm{C}$ in the presence of oxidizing agents (e.g., air, $\mathrm{O}_{2}$, and steam).

In addition to biochar yields, biochar properties are also affected by pyrolysis conditions. Brewer et al. [33] observed biochar from fast pyrolysis and slow pyrolysis had a similar size of fused aromatic ring cluster (7-8 rings per cluster), while the biochar from high-temperature gasification was much more condensed (17 rings per cluster). Moreover, aromatic $\mathrm{C}-\mathrm{H}$ functional groups on the slow pyrolysis char were significantly less prominent than those on the gasification char. Dutta et al. [34] found the biochar from slow pyrolysis was more porous than that from fast pyrolysis.

Slow pyrolysis has inherent drawbacks such as time consumption and low energy efficiency, although it can obtain a high biochar yield. In contrast, fast pyrolysis and gasification are more promising. For more efficient biochar production, some strategies were proposed [15]: (1) to improve the process economics and reduce pollutant emissions through recycling co-products of biochar production; (2) to tailor biochar properties by adjusting pyrolysis conditions and selecting appropriate biomass feedstock. Among the factors that influence biochar properties, the nature of the parent biomass and the pyrolysis temperature are the two important ones [35-37].

\subsubsection{The Influence of Biomass Feedstock}

\section{(1) The Share of Cellulose, Hemicellulose, and Lignin in Raw Biomass}

Cellulose, hemicellulose, and lignin are the main components of lignocellulosic biomass. The three components possess different structural features (e.g., constituting monomer, cross-linking, crystallinity, and branching), which lead to different pyrolysis mechanisms [13,15,38]. Figure 2 illustrates the formation pathway of biochar via cellulose pyrolysis. Consequently, the contents of these components in raw biomass affect the physicochemical properties of the resultant biochar [14,15]. For example, the pyrolysis of high-lignin biomass such as pine wood and spruce wood produces biochar with 
a high yield and a high fixed-carbon content [35]. It is easier for microcrystalline cellulose to produce biochar with graphitic structures at a relatively low temperature (e.g., $350{ }^{\circ} \mathrm{C}$ ) than for lignocellulosic biomass [22].

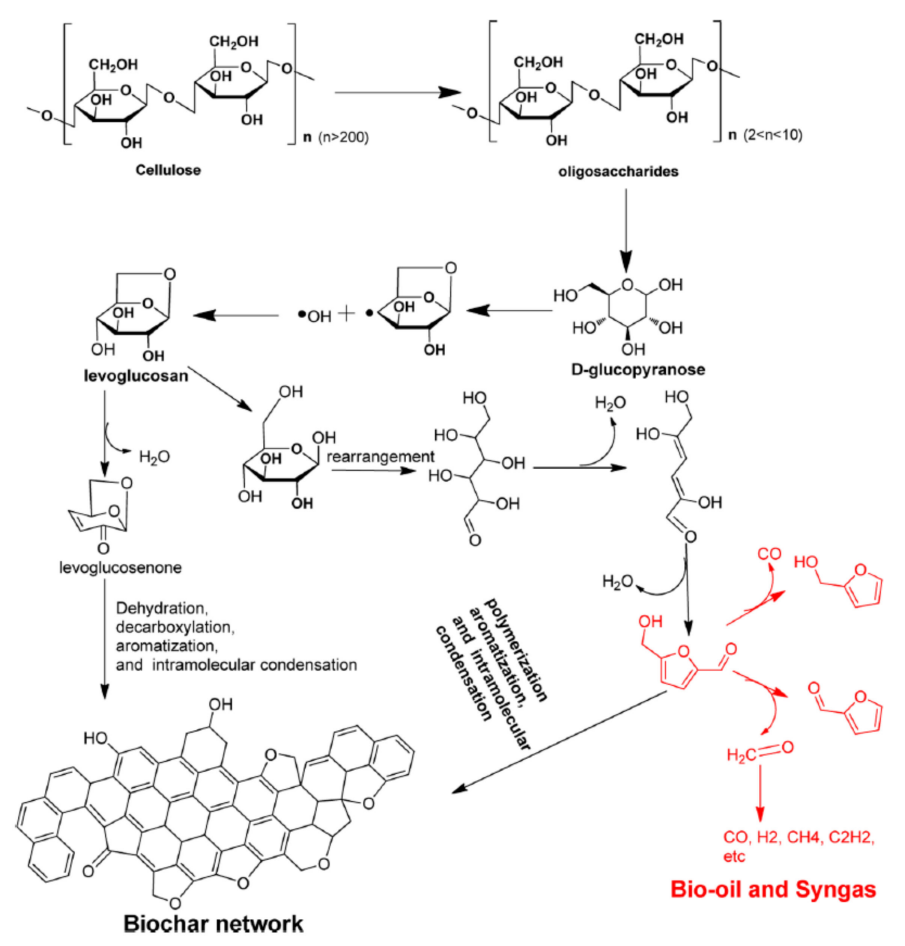

Figure 2. The mechanism of cellulose pyrolysis and biochar formation. Reprinted with permission from Reference [15]. Copyright (2015) American Chemical Society.

\section{(2) The Biomass Matrix}

For some biomasses, their microstructures are basically maintained over a pyrolysis process [14]. As Figure $3 \mathrm{a}, \mathrm{b}$ display, the wood-derived biochar exhibited vertically aligned micro-channels and fibrous ridged surfaces, resembling the morphology of the raw wood $[27,39,40]$. The biochar from sisal leaves (Figure 3c) also inherited the natural hierarchical texture of the original biomass and showed connected porous frameworks [41]. Ordered channel arrays of hollow carbon nanofibers were prepared from the pyrolysis of crab shells [42]. These examples imply that the formation of biochar via biomass pyrolysis is highly "localized" [13].

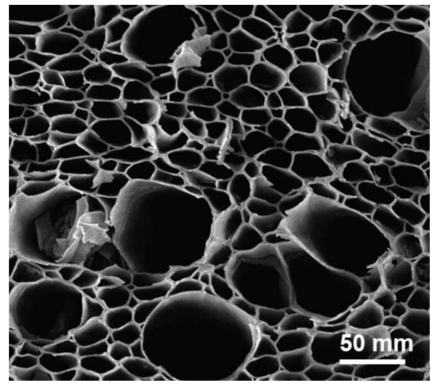

(a)

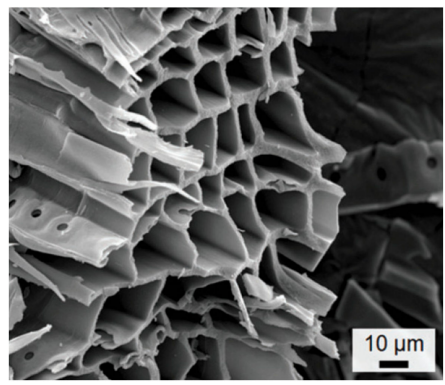

(b)

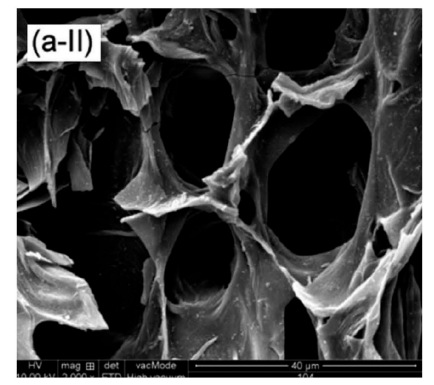

(c)

Figure 3. SEM images of biochar from the pyrolysis of (a) wood block reprinted with permission from [40]. Copyright (2017) American Chemical Society; (b) wood sawdust reprinted with permission from [39]. Copyright (2015) Royal Society of Chemistry; and (c) sisal leaves reprinted with permission from [41]. Copyright (C) 2015, Springer Nature. 
(3) The Inorganic Species

The inorganic species (i.e., ash) in biomass play an important role in the formation of biochar $[14,15]$. Some inorganic elements such as alkali and alkaline earth metals (AAEM) can catalyze biomass pyrolysis, thereby increasing the biochar yield remarkably $[43,44]$. Furthermore, the inorganic species retained in biochar endow biochar with a catalytic activity toward reactions such as methane decomposition [45] and tar cracking [12].

In some cases, inorganic species present in biomass may play a negative role. McBeath et al. [46] reported that a high ash content in feedstock retarded the formation of stable polycyclic aromatic carbon (SPAC), and hence, adversely affected the biochar stability. Yao et al. [47] observed that the presence of $\mathrm{Si}$ in biochar was not favorable for the dispersion of active metal Ni on the biochar support. This was because $\mathrm{Si}$ was easily melted at high temperatures, leading to the sintering of $\mathrm{Ni}$ with ash.

\subsubsection{The Influence of Temperature}

Biochar properties are also greatly influenced by pyrolysis temperatures [10,14,15,48]. Zhang et al. [49] and Zhao et al. [50] reported that temperature affected biochar properties more significantly than heating rate and residence time. They concluded that pyrolysis temperature had a positive correlation with $\mathrm{pH}$, fixed $\mathrm{C}$ content, biochar stability, and ash content, whilst having a negative correlation with biochar yield, $\mathrm{O}$ and $\mathrm{H}$ mass fractions, and the number of surface functional groups.

The pyrolysis temperature also influences the surface area and pore size of biochar. As the temperature rises, more volatiles are released from the biomass surface, resulting in more pores and a larger surface area [15,37,50]. Zhao et al. [50] found that an increase in temperature led to smaller average pore sizes, while Muradov et al. [51] observed that a high pyrolysis temperature could promote the fusion of pores, and thus, expand pore sizes.

The chemical nature of biochar is also closely related to the pyrolysis temperature. Keiluweit et al. [52] revealed the evolution of biochar at a molecular level as the temperature increased. Biochar successively goes through four distinct states, as shown in Figure 4: (i) transition char, in which the constituents of the plant material are partly preserved; (ii) amorphous char, in which the heat-altered molecules and incipient aromatic polycondensates are randomly mixed; (iii) composite char, in which poorly ordered graphene stacks are embedded in amorphous phases; and (iv) turbostratic char, in which disordered graphitic crystallites dominate. McBeath et al. [46] reported that the stable polycyclic aromatic carbon (SPAC) fraction was $20 \%$ of total organic carbon (TOC) at $<450{ }^{\circ} \mathrm{C}$ and $>80 \%$ of TOC at $>600{ }^{\circ} \mathrm{C}$. In general, an elevated temperature could promote the formation of SPAC, and hence, enhance biochar stability. In order to achieve a balance between biochar yield and biochar stability, the optimal temperature was suggested in the range of $500-700{ }^{\circ} \mathrm{C}$ for the commonly used feedstock, such as agricultural and forestry residues [46].

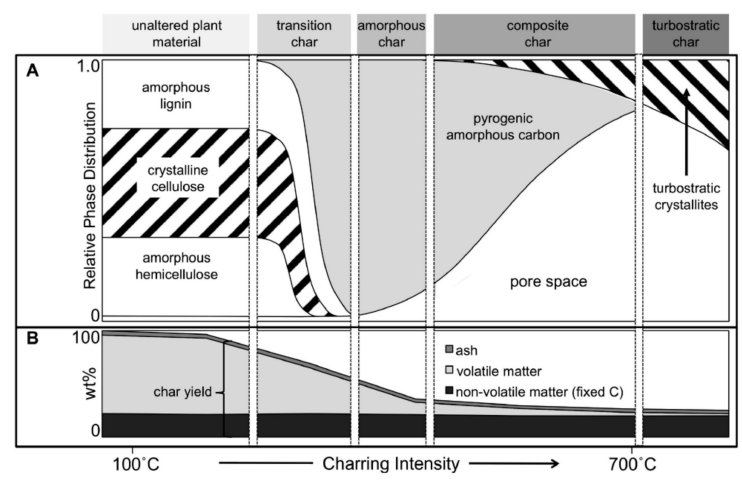

Figure 4. The evolution of biochar as the pyrolysis temperature rises: (A) physicochemical characteristics of organic phases; (B) char composition. Reprinted with permission from Reference [52]. Copyright (2010) American Chemical Society. 


\subsection{Hydrothermal Carbonization}

\subsubsection{Process Description}

A hydrothermal process is normally performed in a closed reactor at temperatures above $180{ }^{\circ} \mathrm{C}$ in the presence of water. The temperature greatly affects the product distribution. Biochar [53-55], bio-oil [56,57], and gaseous products [58-60] are predominantly produced when the temperature is below $250{ }^{\circ} \mathrm{C}$, between $250-400{ }^{\circ} \mathrm{C}$, and above $400{ }^{\circ} \mathrm{C}$, respectively. Accordingly, the three processes are termed as hydrothermal carbonization (HTC), hydrothermal liquefaction, and hydrothermal gasification, respectively.

The solid product from HTC is usually termed hydrochar in order to distinguish it from the char from pyrolysis (i.e., pyrochar) [13]. Depending on biomass feedstock and hydrothermal conditions, the hydrochar yield varies from $30 \%$ to $85 \%[9,17,61-63]$. There is a complex reaction network which involves dehydration, retro-aldol condensation, isomerization, and so on [9]. Possible formation pathways of biochar during HTC were summarized and compared with conventional pyrolysis in Reference [13]. Detailed information on the hydrothermal degradation of biomass components can be found in References [9,64].

Compared to the biochar from pyrolysis, the biochar from HTC has its own characteristics $[64,65]$. Firstly, the hydrochar possesses more surface functional groups. Secondly, spherical micro-sized particles with a limited porosity, as shown in Figure 5, are typically produced during HTC. Due to the small pore size, the surface area and porosity analysis of hydrochar are normally performed using the $\mathrm{CO}_{2}$ isothermal adsorption technique instead of $\mathrm{N}_{2}$ adsorption.

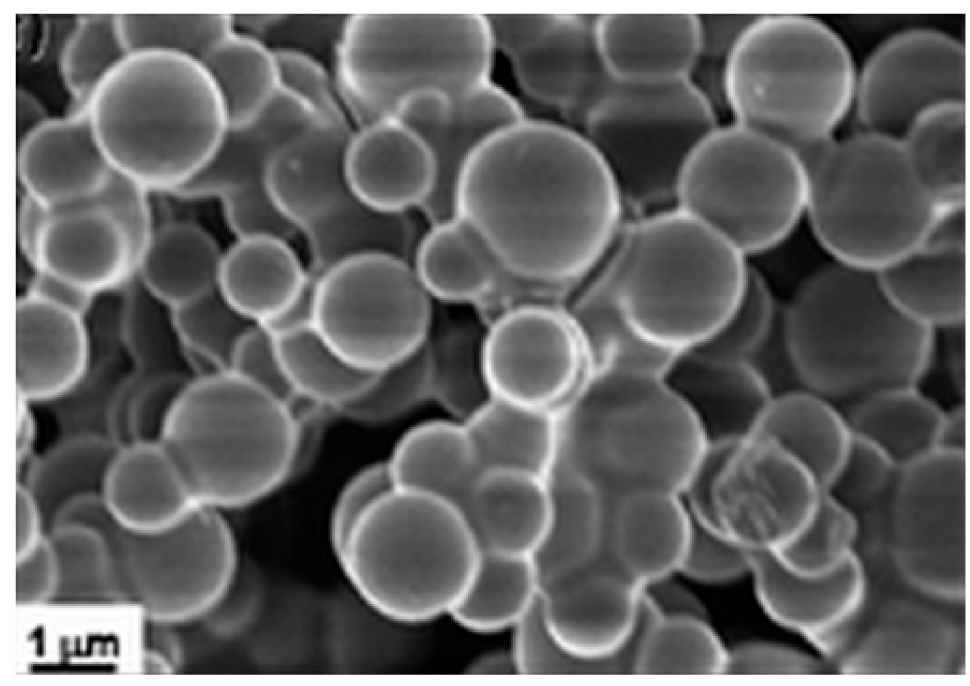

Figure 5. SEM image of biochar prepared from the hydrothermal carbonization of sucrose. Reprinted with permission from Reference [9]. Copyright (2012) Royal Society of Chemistry.

The production of biochar from HTC has several advantages over conventional pyrolysis. Firstly, biomass can be decomposed more easily in an aqueous medium than under pyrolysis conditions $[64,66]$. For example, the decomposition of hemicellulose and cellulose occur at $180^{\circ} \mathrm{C}$ and $230{ }^{\circ} \mathrm{C}$, respectively, under hydrothermal conditions $[67,68]$. In contrast, under pyrolysis conditions, hemicellulose starts decomposing between 200 and $250{ }^{\circ} \mathrm{C}$, and totally degrades at $300{ }^{\circ} \mathrm{C}$ for $2 \mathrm{~h}$. Cellulose begins decomposing at about $270-300{ }^{\circ} \mathrm{C}$ [69]. Secondly, there is no need to dry biomass feedstock for HTC, while energy intensive drying is usually required for conventional pyrolysis. Thus, $\mathrm{HTC}$ is very suitable for processing feedstock with high moisture contents such as aquatic plants and algae $[9,10]$. Lastly, HTC is a convenient technology for coating pre-formed nanostructures with carbonaceous shells. 


\subsubsection{Influencing Factors}

(1) Biomass Feedstock

Monosaccharides and disaccharides are the common feedstock of HTC [70]. Pentoses and hexoses have different HTC mechanisms, with furfural and hydroxymethyl furfural (HMF) as their dehydration products, respectively [71]. Consequently, they yield hydrochar with different sizes. The hydrochar from hexoses (e.g., fructose and glucose) is a spheroid with uniform micrometer size, while the hydrochar from pentoses (e.g., xylose) has a size ranging between 100 and $500 \mathrm{~nm}$. Moreover, ${ }^{13} \mathrm{C}$ solid-state NMR spectroscopic analysis indicated that the pentose-derived hydrochar was more condensed than the hexose-derived hydrochar [9]. As for a disaccharide consisting of two types of monosaccharides, the hydrochar normally has a wide size distribution [72]. This is because different monosaccharides have different kinetics of char formation. Taking sucrose for instance, the size of the hydrochar particles varies from $700 \mathrm{~nm}$ to $2 \mu \mathrm{m}$ [72].

The HTC mechanisms of cellulose and lignocellulosic biomass are fundamentally different from that of glucose [70]. As shown in Figure 6, the polyfuranic intermediate, which is a characteristic of D-glucose-derived hydrochar at either low temperatures or short reaction times, cannot be observed in cellulose-derived hydrochar. In contrast, the cellulose- and the biomass-derived hydrochar show a well-developed aromatic nature, even at the early stage of HTC. Lignin, a component of lignocellulosic biomass, is mildly affected by HTC, and hence, maintains the natural macrostructure of the initial biomass into the final hydrochar.

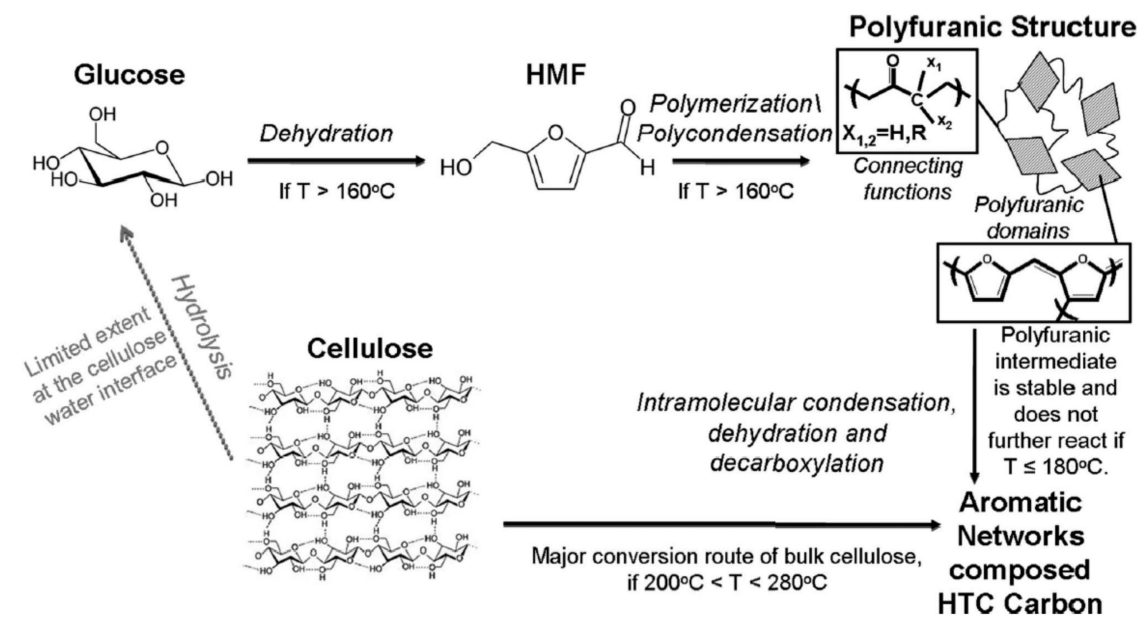

Figure 6. Different hydrothermal carbonization mechanisms for glucose and cellulose under mild processing conditions $\left(180^{\circ} \mathrm{C}<\mathrm{T}<280^{\circ} \mathrm{C}\right)$. Reprinted with permission from Reference [70]. Copyright (2011) Royal Society of Chemistry.

HTC is also applied to various real biomass feedstocks such as paper, food waste, mixed municipal solid waste, anaerobic digestion waste, and olive mill wastewater [61,73]. An elevated operating temperature (e.g., $>200^{\circ} \mathrm{C}$ ) is required for the HTC of real biomass compared with sugars and even pure cellulose [70]. Moreover, the conversion pathways of real biomass to biochar are difficult to construct because of the numerous intermediates.

\section{(2) Hydrothermal Conditions}

The influencing factors of an HTC process include temperature, residence time, and biomass / water ratio $[63,70]$. Titirici et al. [70] demonstrated the effects of temperature on glucose HTC. A change in the temperature allowed a certain degree of control over the char diameter and the char size distribution. Furthermore, raising the temperature was able to switch the chemical structure of the char from polyfuran rich in oxygen-containing functional groups to aromatic networks. Sabio et al. [63] 
investigated the influence of the processing variables on the HTC of tomato peel. A design of experiments/response surface methodology approach was implemented to identify the importance of each variable. Temperature was identified as the major variable, followed by residence time. An increase in both variables markedly decreased the solid yield, but promoted energy densification. In contrast, the biomass/water ratio had a minor effect. In general, a high HTC temperature may result in a low char yield, but a relatively low temperature would lead to the incomplete conversion of biomass and a lower degree of aromatization. Therefore, a multi-step process involving different temperature regimes is suggested for the HTC of real biomass with complex composition [9].

\section{Characteristics of Biochar}

The properties of biochar, which are affected by the biomass feedstock and preparation conditions, determine its potential for a specific application. For example, biochar with a high electrical conductivity and porosity is suitable for electrode materials [74]. Biochar with a high porosity and structurally bound nitrogen groups is preferred for supercapacitor electrode materials [75]. When biochar is intended as a catalyst or catalyst support, its matrix nature, surface functionality, and intrinsic inorganics are key factors.

\subsection{Bulk Elements and Inorganics}

In general, the carbon content of biochar is in the range of 45-60 wt\%, lower than that of carbon black $(>95 \%)$ and coal-derived activated carbon $(80-95 \%)[15,76,77]$. A considerable amount of hydrogen and oxygen elements also exist in biochar. Another feature of biochar is the presence of small amounts of inorganic species such as $\mathrm{K}, \mathrm{Na}, \mathrm{Ca}, \mathrm{Mg}, \mathrm{Si}, \mathrm{Al}, \mathrm{Fe}$, etc. The quantity and the composition of inorganics are highly dependent on the nature of the raw biomass. Woody biomass-derived biochar usually shows a significantly lower content of inorganics than biochar from either herbaceous biomass or hydrophyte biomass $[37,77]$. Some inorganics present in biochar play a crucial role in the catalytic applications of biochar [6], such as for tar cracking [12], bio-oil upgrading [28], and methane decomposition [45].

\subsection{Chemistry of Biochar Matrix}

The biochar matrix is mainly amorphous with some local crystalline structures of highly conjugated aromatic sheets. These aromatic sheets are cross-linked in a random manner as shown in Figure 7. With the processing temperature rising, the size of biochar crystallites increases, and the entire structure becomes more ordered [78]. Additionally, heteroatoms such as N, P, and S from feedstock may be incorporated into the biochar aromatic structure. The difference in the electronegativity between these heteroatoms and the aromatic $\mathrm{C}$ causes the chemical heterogeneity of biochar, which plays an important role in catalytic applications $[79,80]$.

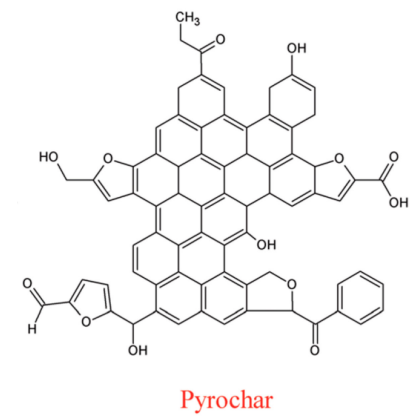

(a)

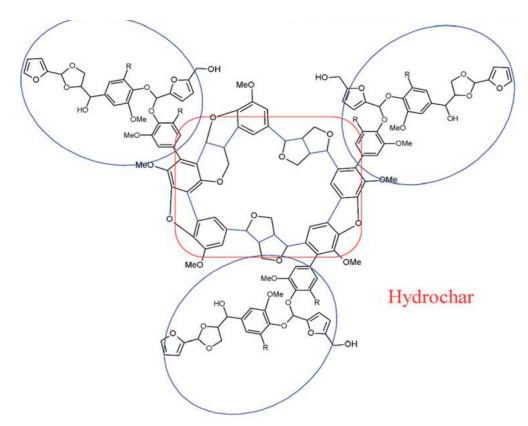

(b)

Figure 7. Chemical structures of pyrochar and hydrochar: (a) chemical structure of pyrochar; (b) chemical structure of hydrochar. Reprinted from Reference [13] published by The Royal Society of Chemistry. 


\subsection{Surface Functional Groups}

In contrast with other carbon materials (e.g., activated carbon and carbon black), biochar usually possesses abundant surface functional groups, as Figure 8 depicts. These surface functional groups are very helpful for biochar functionalization [15,81]. For example, the loading of metal precursors into biochar, a critical step for the synthesis of biochar-supported metal catalysts, can be facilitated by surface functional groups clinching metal cations $[9,13,14]$. In addition, some surface functional groups can improve the performance of biochar-based catalysts for certain reactions. A typical example is shown in biochar-based solid-acid catalysts. Kitano et al. [82] reported that sulfonated carbon material could catalyze the hydrolysis of cellohexaose more effectively than $\mathrm{SO}_{3} \mathrm{H}$-bearing resins. This was because phenolic $\mathrm{OH}$ and $\mathrm{COOH}$ groups in the carbon material functioned as adsorption sites. They concluded that the synergetic combination of the functional groups in biochar could lead to an efficient hydrolysis of $\beta-1,4-$ glucan, including cellulose, on biochar-based solid acids.

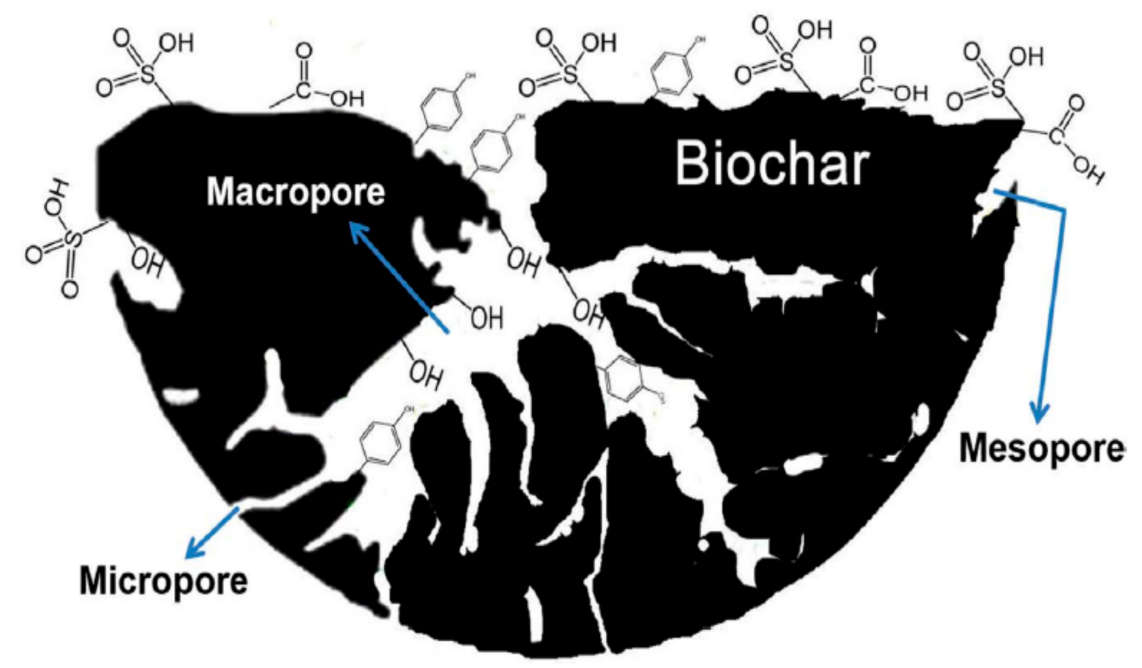

Figure 8. Schematic of porous biochar containing various functional groups. Reprinted with permission from Reference [11]. Copyright (2017) Elsevier Ltd.

\section{Modifications of Biochar}

\subsection{To Produce Porous Structures}

As depicted in Figure 9, heterogeneous catalysis on a porous catalyst usually undergoes several steps [1,11,83]: (1) reactants diffuse from the bulk to the external surface of the catalyst; (2) reactants diffuse to the internal surface through pores; (3) reactants are adsorbed on the catalyst; (4) reactions occur at the active sites; (5) products are desorbed from the catalyst surface; (6) products diffuse to the external surface of the catalyst through catalyst pores; and (7) products diffuse from the external catalyst surface to the bulk. Therefore, the performance of a catalyst highly relies on the accessibility to active sites and the quantity of active sites [83]. An appropriate pore size distribution can improve the catalytic selectivity. A large specific surface area can enhance the dispersity of active substances. A three-dimensional (3D) interconnected porous structure will facilitate the diffusion of reactant and product molecules. In general, the porosity and the surface area are two important properties of catalyst materials. However, originally formed biochar has limited surface area and porosity [77], which hinder its applications in catalysis. This section reviews approaches to preparing porous biochar. 


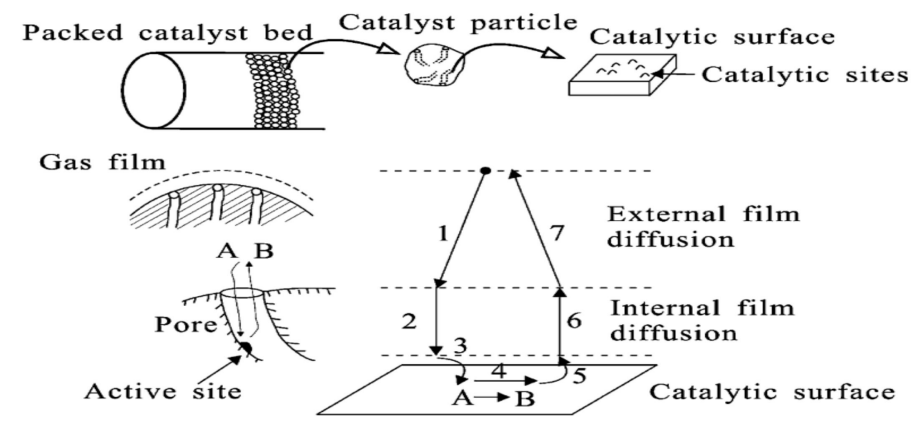

Figure 9. Schematic of the heterogeneous catalysis process on porous catalysts. Reprinted with permission from Reference [1]. Copyright (2009) Royal Society of Chemistry.

\subsubsection{Physical Activation}

Physical activation is usually carried out by exposing the as-prepared biochar to a flow of gasifying agents (steam, $\mathrm{CO}_{2}$, or their mixture) at temperatures above $700{ }^{\circ} \mathrm{C}$. During the process, carbon atoms with a higher reactivity are removed via Reaction (1) or (2) [10,15]. As a result, the porosity and the surface area of biochar are increased. Steam activation is more efficient than $\mathrm{CO}_{2}$ activation, probably due to the faster reaction kinetics between carbon and steam. Duan et al. [84] investigated the influence of different heating methods on the yield and the pore nature of physically activated biochar. Compared to conventional heating, microwave heating could significantly increase the biochar yield for $\mathrm{CO}_{2}$ activation, but showed a negligible effect for steam activation. In addition, the pore volume and the surface area of steam-activated biochar were doubled when using microwave heating instead of conventional heating, while the two morphology parameters of $\mathrm{CO}_{2}$-activated biochar were not changed remarkably.

$$
\begin{gathered}
\mathrm{C}+\mathrm{H}_{2} \mathrm{O}=\mathrm{CO}+\mathrm{H}_{2} \\
\mathrm{C}+\mathrm{CO}_{2}=2 \mathrm{CO}
\end{gathered}
$$

Table 1 shows the effects of physical activation on the structural characteristics of biochar. For instance, Alvarez et al. [85] demonstrated the Brunauer-Emmett-Teller (BET) surface area of rice husk char was enhanced from 227 to $1365 \mathrm{~m}^{2} / \mathrm{g}$ by steam activation at $800{ }^{\circ} \mathrm{C}$ for only $15 \mathrm{~min}$. They found that long activation times would lead to a decrease in the surface area due to the growth and eventual destruction of micropores. Yang et al. [86] increased the surface area of coconut shell char from 702 to above $2000 \mathrm{~m}^{2} / \mathrm{g}$ using physical activation (steam, $\mathrm{CO}_{2}$, or their mixture) under microwave heating. Moreover, they found that an increase in the activation time would lead to a larger BET surface area and a larger pore volume irrespective of the activation agent.

Table 1. The changes in surface area and pore volume of biochar caused by physical activation.

\begin{tabular}{|c|c|c|c|}
\hline Raw materials & $\begin{array}{c}\text { Carbonization (C) or } \\
\text { Activation (A) Conditions }\end{array}$ & $\begin{array}{l}\text { BET Surface } \\
\text { Area }\left(\mathrm{m}^{2} / \mathrm{g}\right)\end{array}$ & $\begin{array}{l}\text { Pore Volume } \\
\qquad\left(\mathrm{cm}^{3} / \mathrm{g}\right)\end{array}$ \\
\hline \multirow{2}{*}{ Rice husk [85] } & \multirow{2}{*}{$\begin{array}{l}\text { C: flash pyrolysis at } 500{ }^{\circ} \mathrm{C} \\
\text { followed by silica removal } \\
\text { A: } 800{ }^{\circ} \mathrm{C} 15 \text { min steam }\end{array}$} & 227 & 0.17 \\
\hline & & 1365 & 1.2 \\
\hline \multirow{4}{*}{ Coconut shell [86] } & \multirow{2}{*}{$\begin{array}{c}\mathrm{C}: 1000{ }^{\circ} \mathrm{C} 2 \mathrm{~h} \mathrm{~N}_{2} \\
\mathrm{~A}: 900{ }^{\circ} \mathrm{C} \text { by microwave heating, } \\
75 \mathrm{~min} \text {, steam }\end{array}$} & 702 & 0.53 \\
\hline & & 2079 & 1.212 \\
\hline & $\begin{array}{c}\text { A: } 900{ }^{\circ} \mathrm{C} \text { by microwave heating, } \\
210 \mathrm{~min}, \mathrm{CO}_{2}\end{array}$ & 2288 & 1.299 \\
\hline & $\begin{array}{c}\text { A: } 900{ }^{\circ} \mathrm{C} \text { by microwave heating, } \\
75 \mathrm{~min} \text {, steam }+\mathrm{CO}_{2}\end{array}$ & 2194 & 1.293 \\
\hline
\end{tabular}
BET: Brunauer-Emmett-Teller. 
Table 1. Cont.

\begin{tabular}{|c|c|c|c|}
\hline Raw materials & $\begin{array}{c}\text { Carbonization }(\mathrm{C}) \text { or } \\
\text { Activation }(\mathrm{A}) \text { Conditions }\end{array}$ & $\begin{array}{l}\text { BET Surface } \\
\text { Area }\left(\mathrm{m}^{2} / \mathrm{g}\right)\end{array}$ & $\begin{array}{l}\text { Pore Volume } \\
\left(\mathrm{cm}^{3} / \mathrm{g}\right)\end{array}$ \\
\hline \multirow{2}{*}{ Rice straw [87] } & $\mathrm{C}: 500{ }^{\circ} \mathrm{C} 1 \mathrm{~h} \mathrm{~N} \mathrm{~N}_{2}$ & 139.5 & 0.092 \\
\hline & A: $700{ }^{\circ} \mathrm{C} 1 \mathrm{~h}$ steam & 363 & 0.164 \\
\hline \multirow{2}{*}{ Sewage sludge [87] } & $\mathrm{C}: 500{ }^{\circ} \mathrm{C} 1 \mathrm{~h} \mathrm{~N} \mathrm{~N}_{2}$ & 18 & 0.018 \\
\hline & A: $700{ }^{\circ} \mathrm{C} 1 \mathrm{~h}$ steam & 64 & 0.039 \\
\hline \multirow{2}{*}{$\begin{array}{l}\text { Sewage sludge with an acid } \\
\text { washing treatment [88] }\end{array}$} & $\begin{array}{c}\text { C: } 700{ }^{\circ} \mathrm{C} 30 \text { min } \mathrm{N}_{2} \text { followed by } \\
\text { acid washing }\end{array}$ & 188 & 0.09 \\
\hline & A: $800^{\circ} \mathrm{C} 2-4 \mathrm{~h} \mathrm{CO}_{2}$ & 269 & 0.11 \\
\hline \multirow{3}{*}{ Jatropha hull [84] } & $\mathrm{C}: 600{ }^{\circ} \mathrm{C} 1 \mathrm{~h} \mathrm{~N} \mathrm{~N}_{2}$ & 480 & 0.42 \\
\hline & A: $900^{\circ} \mathrm{C} 22 \mathrm{~min}$ steam & 748 & 0.53 \\
\hline & A: $950{ }^{\circ} \mathrm{C} 40 \min \mathrm{CO}_{2}$ & 1207 & 0.86 \\
\hline \multirow{2}{*}{ Walnut shell [89] } & $\mathrm{C}: 600{ }^{\circ} \mathrm{C} 1 \mathrm{~h} \mathrm{~N} \mathrm{~N}_{2}$ & 280 & 0.16 \\
\hline & A: $850^{\circ} \mathrm{C} 30 \mathrm{~min}$ steam & 792 & 0.524 \\
\hline \multirow{2}{*}{ Almond tree pruning [89] } & $\mathrm{C}: 600^{\circ} \mathrm{C} 1 \mathrm{~h} \mathrm{~N} \mathrm{~N}_{2}$ & 204 & 0.118 \\
\hline & A: $850^{\circ} \mathrm{C} 30 \mathrm{~min}$ steam & 1080 & 0.95 \\
\hline \multirow{2}{*}{ Almond shell [89] } & $\mathrm{C}: 600{ }^{\circ} \mathrm{C} 1 \mathrm{~h} \mathrm{~N} \mathrm{~N}_{2}$ & 42 & 0.094 \\
\hline & A: $850^{\circ} \mathrm{C} 30 \mathrm{~min}$ steam & 601 & 0.375 \\
\hline \multirow{2}{*}{ Olive stone [89] } & $\mathrm{C}: 600{ }^{\circ} \mathrm{C} 1 \mathrm{~h} \mathrm{~N} \mathrm{~N}_{2}$ & 53 & 0.036 \\
\hline & A: $850^{\circ} \mathrm{C} 30 \mathrm{~min}$ steam & 813 & 0.555 \\
\hline
\end{tabular}

\subsubsection{Chemical Activation}

Chemical activation is usually performed by adding activators to biomass precursors followed by a routine carbonization. In this case, chemical activation and carbonization occur simultaneously (in situ activation). Sometimes, chemical activators are added to pre-formed biochar followed by a thermal treatment [15,90-92]. The post-activation method is especially useful for biochar from HTC [64]. Compared with physical activation, chemical activation can create porous structures at a relatively lower temperature $[87,90]$. However, several issues, such as equipment corrosion, chemical recycling, product purification, etc., need to be considered when using chemical activation. Common activators include $\mathrm{KOH}, \mathrm{K}_{2} \mathrm{CO}_{3}, \mathrm{H}_{3} \mathrm{PO}_{4}, \mathrm{ZnCl}_{2}$, etc. Different activators may have different activation mechanisms.

\section{(1) Alkali Metal Activators}

Alkali metal activators include alkali hydroxides (e.g., $\mathrm{NaOH}, \mathrm{KOH}$, and $\mathrm{LiOH}$ ), alkali carbonates (e.g., $\mathrm{Na}_{2} \mathrm{CO}_{3}$ and $\mathrm{Li}_{2} \mathrm{CO}_{3}$ ), alkali hydro-carbonates (e.g., $\mathrm{KHCO}_{3}$ ), etc.

When $\mathrm{KOH}$ is used as an activator, Reactions (3)-(6) may occur $[8,15,93]$. Pores are generated due to a synergistic effect of several factors. Firstly, $\mathrm{KOH}$, as well as its intermediates $\mathrm{K}_{2} \mathrm{CO}_{3}$ and $\mathrm{K}_{2} \mathrm{O}$, etches biochar through chemical Reactions (3), (5), and (6). Secondly, the escape of gaseous products (e.g., $\mathrm{CO}$ and $\mathrm{H}_{2}$ ) from the biochar interior leads to the formation of macropores, similar to a leaving process [41]. Furthermore, $\mathrm{H}_{2} \mathrm{O}$ and $\mathrm{CO}_{2}$ in situ formed during carbonization may cause a physical activation. Lastly, the metallic $\mathrm{K}$ produced intercalates into the biochar matrix during activation, resulting in an expansion of the biochar lattice [94].

$$
\begin{aligned}
6 \mathrm{KOH}+2 \mathrm{C} & \rightarrow 2 \mathrm{~K}+3 \mathrm{H}_{2} \uparrow+2 \mathrm{~K}_{2} \mathrm{CO}_{3} \\
6 \mathrm{KOH}+\mathrm{CO}_{2} & \rightarrow \mathrm{K}_{2} \mathrm{CO}_{3}+\mathrm{H}_{2} \mathrm{O} \uparrow \\
\mathrm{K}_{2} \mathrm{CO}_{3}+2 \mathrm{C} & \rightarrow \mathrm{K}_{2} \mathrm{O}+2 \mathrm{CO} \uparrow \\
\mathrm{K}_{2} \mathrm{O}+\mathrm{CO} & \rightarrow 2 \mathrm{~K}+\mathrm{CO} \uparrow
\end{aligned}
$$




$$
2 \mathrm{KHCO}_{3} \rightarrow \mathrm{K}_{2} \mathrm{CO}_{3}+\mathrm{CO}_{2}+\mathrm{H}_{2} \mathrm{O}
$$

Cha et al. [87] reported that both rice-straw char and sewage char were effectively activated by $\mathrm{KOH}$, and increases in their surface areas from 140 to $772 \mathrm{~m}^{2} / \mathrm{g}$ and from 18 to $783 \mathrm{~m}^{2} / \mathrm{g}$ were achieved, respectively. Bhandari et al. [95] enhanced the effect of $\mathrm{KOH}$ activation by sonicating a mixture of biochar and $\mathrm{KOH}$ solution. Sevilla et al. [96] employed $\mathrm{KOH}$ to activate an HTC biochar and achieved a high surface area (up to $2700 \mathrm{~m}^{2} / \mathrm{g}$ ) and a narrow pore size distribution (PSD; 0.7-2 nm). Li et al. [41] created both macropores and mesopores on the biochar of sisal leaves using $\mathrm{LiOH}$ and $\mathrm{Li}_{2} \mathrm{CO}_{3}$ activators, as Figure 10 shows. The formation of pores was attributed to the chemical corrosion of $\mathrm{LiOH}$ and $\mathrm{Li}_{2} \mathrm{CO}_{3}$ on biochar, similar to Reactions (3) and (5).

II

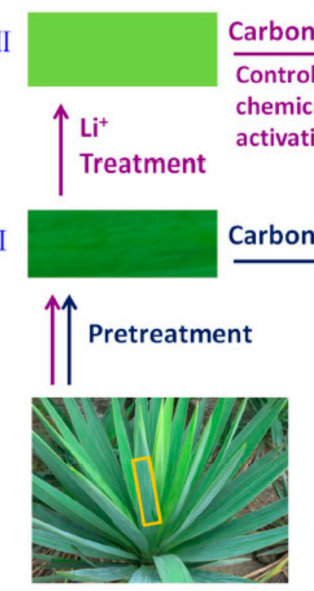

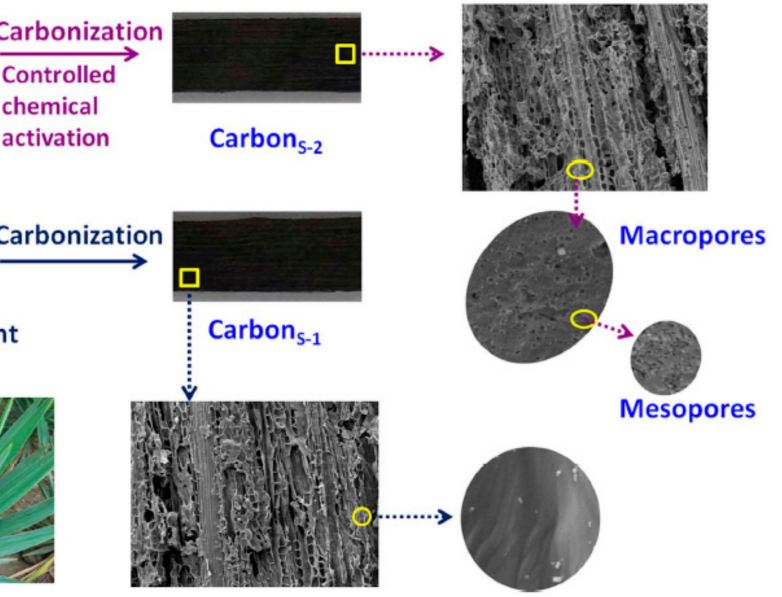

Figure 10. The preparation of porous biochar via simultaneous carbonization and controlled chemical activation. Reprinted from Reference [41].

$\mathrm{KHCO}_{3}$ was also used as an activator for the synthesis of hierarchically porous biochar through a simple one-pot approach [97]. Using this method, biochar with 3D hierarchical pores (macro-, meso-, and micropores) and a large surface area (up to $1893 \mathrm{~m}^{2} / \mathrm{g}$ ) could be obtained. Macropores were formed due to the gas evolution from $\mathrm{KHCO}_{3}$ decomposition (Reaction (7)), resembling bread fermentation. Mesopores and micropores were generated through reactions (5) and (6).

\section{(2) $\mathrm{H}_{3} \mathrm{PO}_{4}$ Activator}

$\mathrm{H}_{3} \mathrm{PO}_{4}$ is another commonly used activator for the production of porous biochar. Lobos et al. [98] reported that a pre-treatment of cellulose with $5 \% \mathrm{H}_{3} \mathrm{PO}_{4}$ prior to pyrolysis led to an increase in the surface area of biochar from 199 to $557 \mathrm{~m}^{2} / \mathrm{g}$, and an increase in the pore volume from 0.026 to $0.22 \mathrm{~cm}^{3} / \mathrm{g}$. Moreover, the concentration of structural defects (i.e., terraces, steps, and kinks) in the biochar was also increased, which promoted the dispersion of metal precursors onto the biochar support. Shen et al. [20] also demonstrated that the surface area of biochar from cotton stalks could be significantly enhanced from 516 to $1955 \mathrm{~m}^{2} / \mathrm{g}$ using $\mathrm{H}_{3} \mathrm{PO}_{4}$ activation.

The addition of $\mathrm{H}_{3} \mathrm{PO}_{4}$ into biomass precursors affects biomass pyrolysis [15]. At temperatures below $200{ }^{\circ} \mathrm{C}, \mathrm{H}_{3} \mathrm{PO}_{4}$ promotes the hydrolysis of hemicellulose and cellulose, and cleaves the aryl ether bonds of lignin. Additionally, $\mathrm{H}_{3} \mathrm{PO}_{4}$ helps cross-link the polymer chains by forming ester linkages with $-\mathrm{OH}$ groups [99]. As the temperature goes up, the $\mathrm{P}-\mathrm{O}-\mathrm{C}$ bonds are broken, and cyclization and condensation reactions occur, leading to an increase in the aromaticity of biochar. Furthermore, $\mathrm{H}_{3} \mathrm{PO}_{4}$ can improve the separation of cellulose microfibers by swelling the biomass structure, resulting in the formation of open pores. 


\section{(3) $\mathrm{ZnCl}_{2}$ Activator}

The activation mechanism of $\mathrm{ZnCl}_{2}$ was summarized by Reference [15]. $\mathrm{ZnCl}_{2}$ can intrude into the biomass interior at low temperatures, and it maintains in a liquid state throughout the entire pyrolysis process $\left(<700^{\circ} \mathrm{C}\right)$. As a result, $\mathrm{ZnCl}_{2}$ is evenly distributed in the matrix of the resulting biochar. By removing $\mathrm{ZnCl}_{2}$, a well-developed microporous biochar could be obtained. In addition, $\mathrm{ZnCl}_{2}$ could decrease the carbonization temperature of biomass components due to its strong dehydration capacity at elevated temperatures. Furthermore, the presence of $\mathrm{ZnCl}_{2}$ changes the decomposition pathways of biomass, and suppresses the tar formation.

Ucar et al. [100] employed $\mathrm{ZnCl}_{2}$ to prepare activated biochar from pomegranate seeds. The surface area was strongly influenced by the $\mathrm{ZnCl}_{2}$ impregnation ratio and the carbonization temperature. When using an impregnation ratio of 2.0 and a carbonization temperature of $600{ }^{\circ} \mathrm{C}$, the specific surface area of the resultant biochar was as high as $978.8 \mathrm{~m}^{2} / \mathrm{g}$. Sun et al. [101] prepared sheet-like graphitic biochar with a surface area of $1874 \mathrm{~m}^{2} / \mathrm{g}$ and a total pore volume of $1.21 \mathrm{~cm}^{3} / \mathrm{g}$ by simultaneously applying a $\mathrm{ZnCl}_{2}$ activator and a graphitic catalyst precursor, $\mathrm{FeCl}_{3}$, on coconut shell biomass waste.

\subsubsection{Templating Methods}

A hard-templating approach (also termed nanocasting) is normally carried out as follows: firstly, a pre-formed porous solid template is impregnated with a biomass precursor and subjected to a carbonization procedure. Then, the original scaffold is removed, and a carbonaceous porous replica is obtained. This approach is especially useful for the production of porous biochar via HTC. Titirici's research group does a lot of work in this field [102-105]. When using silica template Si-100 in the HTC of glucose or furfural [102], biochar with different morphologies (e.g., mesoporous microspheres, mesoporous hollow spheres, carbon nanoparticles, and macroporous casts) was obtained by simply altering the polarity of the silica surface. When adding silica template SBA-15 into the HTC of furfural, ordered mesoporous biochar with functional groups residing at the pore surface was fabricated [103]. Uniform, open-ended carbonaceous tubular nanostructures were also prepared using a macroporous alumina membrane template in the HTC of furfural [104]. In order to remove templates, harsh and non-environmentally friendly solvents are usually used in the hard-templating method, whereas a soft-templating approach does not have this problem. Kubo et al. [106] fabricated both ordered microporous and mesoporous biochar materials via a combined HTC/soft-templating approach with the block copolymer, Pluronic, as a structure-directing agent, and D-fructose as a carbon source. White et al. [105] prepared hollow carbonaceous nanospheres by adding latex into the HTC of glucose. Figure 11 displays three typical porous structures synthesized via the templating method.

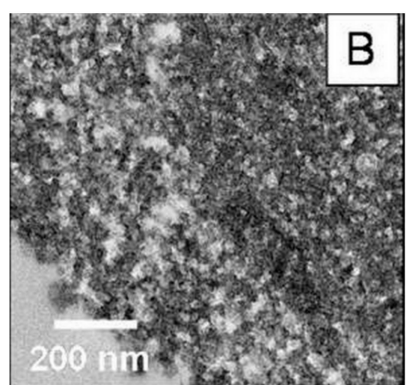

(a)

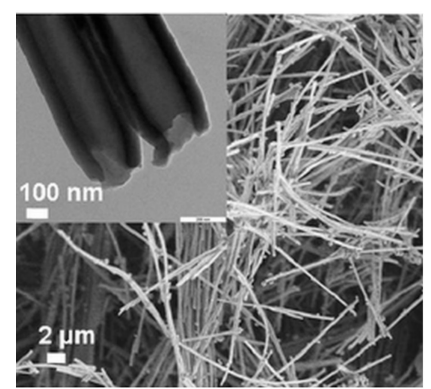

(b)

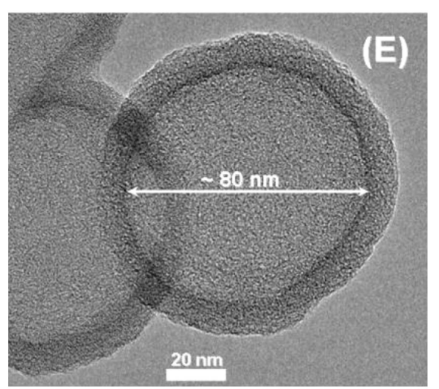

(c)

Figure 11. TEM images of porous biochar prepared via templating methods: (a) mesoporous microspheres, reprinted with permission from Reference [102]. Copyright (2007) John Wiley and Sons; (b) tubular structures, reprinted with permission from Reference [104]. Copyright (2010) American Chemical Society; (c) hollow nanospheres, reprinted with permission from Reference [105]. Copyright (2010) American Chemical Society. 
In addition to artificial templates, inorganic components naturally present in biomass precursors are also employed to aid the formation of pores. For instance, prawn shells, a high-volume food waste, were successfully converted to mesoporous biochar via an HTC process followed by the removal of its inherent mineral $\mathrm{CaCO}_{3}$ with acid washing [107].

\subsection{Surface Functionalization}

\subsubsection{Surface Acidification}

The surface acidification of biochar is usually used to synthesize biochar-based solid acid, a catalyst for reactions such as polysaccharide hydrolysis [5,108-113], esterification, and transesterification [2,114-116].

Sulfonation is a common method for surface acidification. Its product, biochar bearing $\mathrm{SO}_{3} \mathrm{H}$, represents a typical class of solid Brønsted acids. The sulfonation of biochar can be implemented via two approaches. The first approach is to immerse biochar in sulfuric acid solution $[2,5,112-114,116,117]$. The mixture is stirred at temperatures between 90 and $200{ }^{\circ} \mathrm{C}$ followed by washing and drying. Using this method, the concentration of acid sites on the biochar surface can be up to $2.5 \mathrm{mmol} / \mathrm{g}$ [118]. The second approach is to expose biochar to $\mathrm{SO}_{3}$ gas $(>20 \%$ ) at temperatures between 25 and $150{ }^{\circ} \mathrm{C}[2,114]$. Kastner et al. [114] compared the two sulfonation methods. Their results indicated that $\mathrm{SO}_{3}$ sulfonation could generate higher $-\mathrm{SO}_{3} \mathrm{H}$ densities, whereas $\mathrm{H}_{2} \mathrm{SO}_{4}$ sulfonation could clearly increase the surface area and pore volume of biochar. Other studies $[116,119]$ indicated that both sulfonation methods would lead to a reduction in the surface area of the biochar.

In addition, copolymerization under hydrothermal conditions can also introduce acid groups into the biochar. Liang et al. [120] prepared $\mathrm{SO}_{3} \mathrm{H}$-bearing biochar through the one-step HTC of furfural and hydroxyethyl-sulfonic acid at $180^{\circ} \mathrm{C}$ for $4 \mathrm{~h}$. Qi et al. [108] synthesized biochar-based solid acids containing $-\mathrm{SO}_{3} \mathrm{H}$ and $-\mathrm{COOH}$ groups via the in situ hydrothermal copolymerization of glucose with sulfosalicylic acid and acrylic acid, respectively.

\subsubsection{Surface Amination}

The surface amination of biochar can be performed via three methods. The common method is to treat biochar with $\mathrm{NH}_{3}$ at elevated temperatures [121-124]. In order to increase the surface reactivity of biochar toward $\mathrm{NH}_{3}$, surface oxidation is usually conducted prior to surface amination. This method is simple, but attention needs to be paid to the leakage of $\mathrm{NH}_{3}$ during handling. Another method is to anchor amino-containing reagents such as tris(2-aminoethyl)amine [125] and polyethylenimine [126] on the biochar surface through condensation reactions between amino or imino groups and carboxyl groups. Surface amination can also be achieved through nitration followed by reduction. Using this method, nitro groups are first introduced into the biochar surface, before being reduced to amino groups [15].

\subsubsection{Surface Oxidation}

Surface oxidation is to produce extra oxygenated functional groups (e.g., carboxyl, hydroxyl, phenolic groups, etc.) on the biochar surface. It is usually carried out by thermally treating biochar under aerobic conditions. Chen et al. [127] markedly increased the concentration of oxygen-containing functional groups, especially carboxyl groups (from 0.53 to $3.70 \mathrm{mmol} / \mathrm{g}$ ) on the surface of hydrochar by simply heating the hydrochar at $300{ }^{\circ} \mathrm{C}$ in air. In addition to thermal treatment in air, the utilization of oxidizing reagents such as $\mathrm{H}_{2} \mathrm{O}_{2}, \mathrm{O}_{3}, \mathrm{HNO}_{3}$, and $\mathrm{KMnO}_{4}$ can also achieve surface oxidation [128-131]. $\mathrm{Li}$ et al. [131] modified the surface of bamboo-derived biochar via the chemical method. A large number of acidic functional groups were created on the biochar surface, with $\mathrm{HNO}_{3}$ being more effective than $\mathrm{KMnO}_{4}$. They also found that the chemical treatment increased the hydrophilicity of biochar, while the thermal treatment caused an opposite effect. 


\subsection{In Situ Heteroatom Doping}

Heteroatom doping (e.g., N [107,132-134], S [135], and P [136]) can alter the physicochemical properties of carbonaceous materials and improve their performance in catalysis, adsorption, or energy storage. For example, Nagy et al. [134] reported that the electrocatalytic activity of mesoporous carbon aerogels for oxygen reduction reactions increased with the content of $\mathrm{N}$ doping. Various strategies were proposed to incorporate $\mathrm{N}$ into biochar. Compared to annealing biomass precursors under $\mathrm{NH}_{3}$ [132] or with $\mathrm{NH}_{4} \mathrm{NO}_{3}$ [137], the direct carbonization of $\mathrm{N}$-containing biomass is more favorable $[138,139]$ because of the facile operation and sustainable feedstock.

\subsubsection{Utilize Amino-Containing Biomass Feedstock}

Amino-containing carbohydrates are common feedstock for the production of N-doped biochar. Zhao et al. [138] successfully synthesized N-doped biochar $(>8.9 \% \mathrm{~N}$ and $6.6 \% \mathrm{~N})$ through the HTC of chitosan and D-glucosamine, respectively, at $180^{\circ} \mathrm{C}$. Under hydrothermal conditions, D-glucosamine firstly decomposed into HMF and ammonia, before forming an aromatic network containing pyrrole and pyridine-type N functionalities. Prawn shells and king-crab shells, natural sources of chitin (poly- $\beta(1-4)-N$-acetyl-D-glucosamine), were also successfully utilized to fabricate $\mathrm{N}$-doped porous biochar via HTC [107] or pyrolysis [140].

\subsubsection{Add N-Containing Molecules to Biomass Feedstock}

Another method for in situ $\mathrm{N}$-doping is to add $\mathrm{N}$-containing molecules such as protein and amino acids into biomass feedstock. White et al. [141] reported the hydrothermal synthesis of N-doped monolithic carbon aerogels with D-glucose and ovalbumin as feedstock. The protein acted as not only an N donor, but also a surface stabilizing agent during the HTC of glucose, resulting in the formation of high-surface-area aerogels with continuous mesopores. Baccile et al. [142] prepared N-doped biochar via the HTC of glucose and glycine, and studied the chemical structure of the resulting biochar. They found $\mathrm{N}$-containing aromatic domains and polyfuran networks coexisted in this material. In contrast to biochar obtained from pure carbohydrates, the $\mathrm{N}$-containing biochar displayed a higher degree of aromatization. Algae, a class of N-containing biomass abundant on Earth, can also be used as a secondary biomass precursor for the production of $\mathrm{N}$-doped biochar [9].

\subsection{To Form Composites}

For some reactions, biochar itself has little catalytic activity, and thus, it is necessary to load the biochar with active substances. This section summarizes the synthesis method of three common biochar-based composites.

\subsubsection{Biochar/Metal Composites}

\section{(1) One-Step Method}

Biochar/metal composites can be synthesized by subjecting the mixture of biomass and metal precursor to a carbonization condition (pyrolysis [143-147] or HTC [148-150]). During the process, the biomass is converted to biochar and the high-valence metal precursor is reduced in situ [15]. The one-step approach has several advantages. Firstly, the operation is simple. Secondly, the gaseous or solid products of biomass decomposition could act as reducing agents, thus avoiding the use of additional reagents (atom economy). Lastly, the metal nanoparticles formed can catalyze the biomass carbonization and improve the quality of the biochar [143-145,151].

Various biochar/base-metal composites were prepared using this method. Richardson et al. [143] synthesized biochar-supported $\mathrm{Ni}$ metal nanoparticles (NPs) by pyrolyzing $\mathrm{Ni}^{2+}$-impregnated wood between 400 and $500{ }^{\circ} \mathrm{C}$. The formation mechanism of Ni NPs was deeply investigated. Firstly, $\mathrm{Ni}$ ions were adsorbed onto the biochar with surface functional groups as adsorption sites. Then, an amorphous $\mathrm{Ni}_{x} \mathrm{O}_{y} \mathrm{H}_{z}$ phase was formed during the pyrolysis process. Lastly, the $\mathrm{Ni}_{x} \mathrm{O}_{y} \mathrm{H}_{z}$ phase 
was reduced to metallic $\mathrm{Ni}\left(\mathrm{Ni}^{0}\right)$ by gaseous or solid products of biomass pyrolysis. Their group [144] later found that the in situ generated $\mathrm{Ni}^{0} \mathrm{NPs}$ exhibited a higher catalytic activity for tar conversion than pre-formed $\mathrm{Ni}^{0} \mathrm{NPs}$ that were inserted into the biomass prior to pyrolysis. Liu et al. [147] utilized fir sawdust to absorb metal ions (i.e., $\mathrm{Cu}^{2+}$ and $\mathrm{Fe}^{3+}$ ) from synthetic wastewater, and then converted the metal-polluted biomass to metallic $\mathrm{Cu}$-anchored magnetic biochar $\left(\mathrm{Cu} \& \mathrm{Fe}_{3} \mathrm{O}_{4}-\mathrm{mC}\right)$ via fast pyrolysis.

Similarly, the one-step method was also employed to prepare biochar/noble-metal composites. Yu et al. [150] synthesized noble metals supported on various carbon nanoarchitectures (e.g., nanocables, hollow tubes, and hollow spheres) via the mild HTC of starch in the presence of noble-metal salts. Here, starch acted as the carbon source and reducing agent. Noble-metal salts functioned as the metal source and the catalyst for biomass carbonization. Makowski et al. [148] prepared a Pd@hydrophilic-C nanocomposite via the HTC of furfural and palladium acetylacetonate at $190{ }^{\circ} \mathrm{C}$ for $14 \mathrm{~h}$. Yu et al. from the Chinese University of Hong Kong [149] demonstrated the one-pot synthesis of coaxial Ag/C nanocables via the microwave-assisted HTC of sucrose and $\mathrm{AgNO}_{3}$. Fang et al. [152] prepared Ag/C core/shell nanoparticles and nanocables via the HTC of ascorbic acid in the presence of $\mathrm{Ag}^{+}$and cetrimonium bromide (CTAB). The concentration of CTAB determined the final morphology of the product.

\section{(2) Two-Step Method}

Biochar/metal composites can also be prepared using a two-step procedure. The first step is biomass carbonization (pyrolysis or HTC) to produce biochar. The second step is to impregnate the as-formed biochar with metal salts followed by the transformation of metal ions to metals through carbothermal reduction [153] or surface redox reactions [154].

Yao et al. [47] prepared a biochar-supported $\mathrm{Ni}$ catalyst by impregnating biochar with an aqueous solution of $\mathrm{Ni}\left(\mathrm{NO}_{3}\right)_{2} \cdot 6 \mathrm{H}_{2} \mathrm{O}$, then drying at $105{ }^{\circ} \mathrm{C}$ overnight, followed by calcination under $\mathrm{N}_{2}$ atmosphere at $800^{\circ} \mathrm{C}$. Their results suggested the Ni catalyst was efficient for hydrogen production from biomass steam gasification. Yan et al. [31] prepared a carbon-encapsulated Fe catalyst by thermally treating $\mathrm{Fe}\left(\mathrm{NO}_{3}\right)_{3}$-impregnated pine-wood char at $1000{ }^{\circ} \mathrm{C}$ for $1 \mathrm{~h}$. Shen et al. [153] prepared biochar-supported $\mathrm{Ni} / \mathrm{Fe}$ bimetallic catalysts by using the two-step approach with $\mathrm{Fe}\left(\mathrm{NO}_{3}\right)_{3} \cdot 9 \mathrm{H}_{2} \mathrm{O}$ and $\mathrm{Ni}\left(\mathrm{NO}_{3}\right)_{2} \cdot 6 \mathrm{H}_{2} \mathrm{O}$ as metal precursors. Figure 12 illustrates the preparation process.

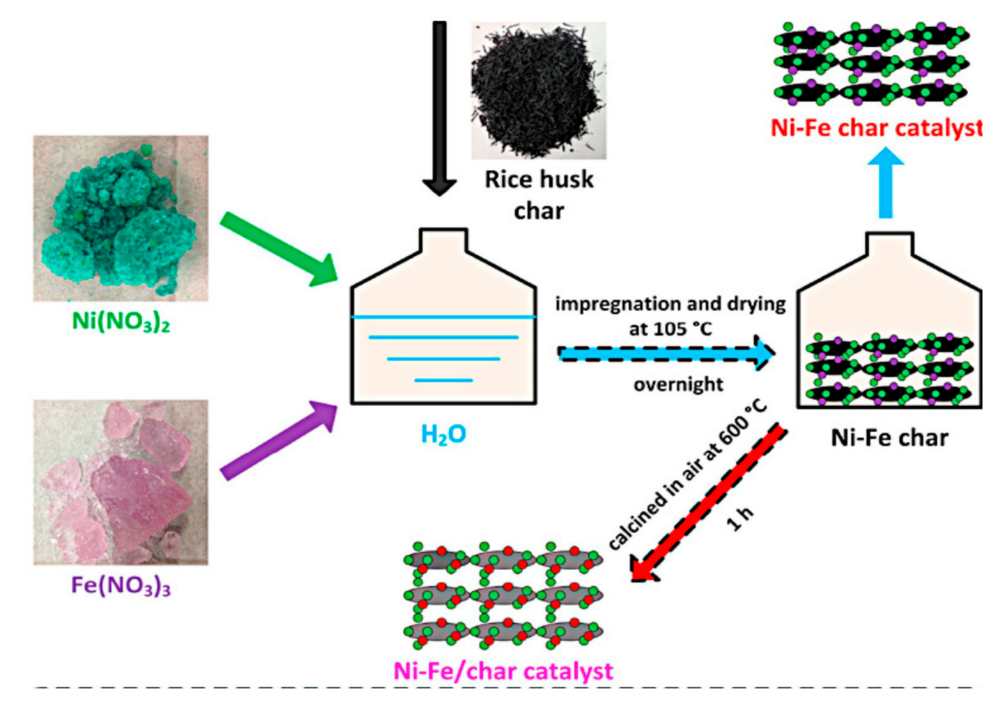

Figure 12. Schematic of a two-step method for the synthesis of an Ni/Fe-char catalyst, reprinted with permission from Reference [153]. Copyright (2014) Elsevier B.V. 
Biochar derived from HTC has abundant surface functionalities. These surface functional groups could adsorb and in situ reduce noble-metal ions at a relatively low temperature, resulting in the formation of noble-metal/biochar hybrids [154-157]. Using this method, Sun and Li [154] successfully loaded Ag and Pt NPs onto the surface of colloidal hydrochar spheres at room temperature or in a reflux setup. After the metal loading, the number of reducing functional groups (e.g., $-\mathrm{OH}$ ) on the hydrochar surface was reduced due to the occurrence of a surface redox reaction. Qian et al. [156] decorated carbon nanofibers prepared via HTC with fine noble-metal NPs such as Pd, Pt, and Au, through a redox reaction between the carbon fibers and noble-metal salts. These carbon-nanofiber-supported noble metals possessed stability, a large surface area, and high chemical reactivity. Therefore, they were considered as ideal candidates for heterogeneous catalysis.

\section{(3) Coating Pre-Formed Metals with Biomass Followed by Carbonization}

Biochar/metal composites can also be prepared by coating the pre-formed metal nanostructures with biomass before carbonization. This method is very useful for cases where (1) the carbonization condition (e.g., HTC) is unable to reduce metal ions; and (2) metals with special nanostructures are desired, but cannot be achieved by in situ growth. Sun and Li [154] prepared Ag-cored biochar spheres using Ag NPs as nuclei for the growth of biochar spheres under HTC conditions. Qian et al. [158] successfully synthesized uniform Te@C nanocables by adding pre-formed Te nanowires into an HTC container of D-glucose. The Te nanowires not only restrained the homogeneous nucleation of carbonaceous spheres, but also promoted the deposition of a carbonaceous shell. Moreover, the diameter of the final nanocables could be easily adjusted by changing the HTC duration or the ratio of Te to D-glucose.

\subsubsection{Biochar/Carbide Composites}

When metal-salt-impregnated biomass or biochar is subjected to a thermal treatment, the metal element may transform in the following order with the temperature rising: metal salt $\rightarrow$ metal oxide $\rightarrow$ metal $\rightarrow$ metal carbide. Biomass or biochar acts not only as a reducing agent, but also as a C-provider for the production of metal carbides.

Yan et al. [159] synthesized tungsten carbide (WC) NPs that were embedded in a biochar matrix by thermally processing ammonium-tungstate-impregnated biochar at $1000{ }^{\circ} \mathrm{C}$ under $\mathrm{N}_{2}$. The WC NPs were produced through the following process: $\mathrm{WO}_{3} \rightarrow \mathrm{WO}_{2} \rightarrow \mathrm{W} \rightarrow \mathrm{W}_{2} \mathrm{C} \rightarrow \mathrm{WC}$. Zhang et al. [160] prepared a mesoporous biochar-supported $W C_{x}$ catalyst by impregnating the biochar with ammonium metatungstate followed by carbothermal hydrogen reduction at $900{ }^{\circ} \mathrm{C}$. In addition to $\mathrm{WC}_{\mathrm{x}}$, other carbides such as $\mathrm{Fe}_{3} \mathrm{C}$ [39], $\mathrm{SiC}[161,162], \mathrm{B}_{4} \mathrm{C}[163,164], \mathrm{TiC}[165,166]$, and MoC [167] were also prepared in a biochar matrix using this method.

\subsubsection{Biochar/Nanostructured Carbon Material Composites}

The hybridization of biochar with other nanostructured carbon materials can achieve unique physiochemical properties. Surface functional groups and inorganic species present in biochar are beneficial to this combination to some extent. Inyang et al. [168] coated biochar with multi-walled carbon nanotubes (CNTs) by impregnating biomass with carboxyl-functionalized CNT solutions followed by slow pyrolysis. The physiochemical properties (e.g., surface area, porosity, and thermal stability) of the resultant composite were much better than that of the biochar itself. Chen et al. [169] reported the direct synthesis of carbon nanofibers on activated biochar using the chemical vapor deposition of ethylene. The Fe present in the ash content of the biochar in situ catalyzed the growth of carbon nanofibers according to a "tip-growing" mechanism [170]. Consequently, Fe particles were on the tip of the carbon nanofibers, as displayed in Figure 13. 


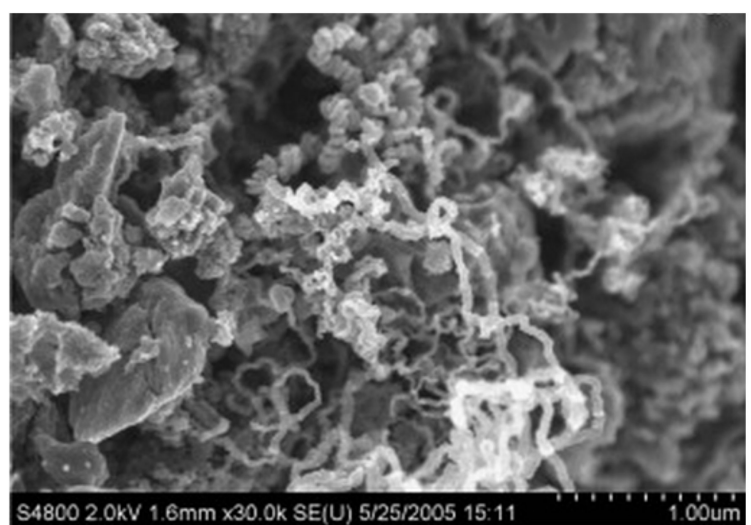

(a)

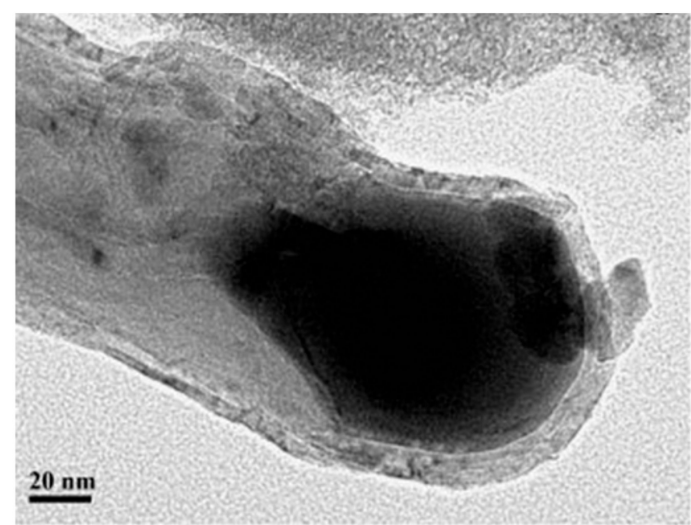

(b)

Figure 13. (a) SEM image of carbon nanofibers supported on biochar; (b) TEM image of a carbon nanofiber with an Fe particle on the tip. Reprinted with permission from Reference [169]. Copyright (2008) Elsevier Ltd.

\section{Applications of Biochar-Based Catalysts for Biofuel Production}

The use of biochar as a catalyst or catalyst support has several advantages [16]. Firstly, the production process of biochar is simple and low-cost owing to sustainable biomass resources and well-developed synthesis techniques. Secondly, the physicochemical properties of biochar can be easily tuned using various strategies. Thirdly, some intrinsic features of biochar, such as surface functional groups, the presence of inorganic species, a hierarchical structure inherited from biomass matrix, etc., may play an important role in its catalytic applications [14]. Finally, a synergic effect between active metals and the biochar support for its catalytic performance may exist in some cases [31,171]. This section discusses the application of biochar-based catalysts in biodiesel production, biomass hydrolysis, and tar reduction, which represent three main branches of biomass upgrading.

\subsection{Biodiesel Production}

Biodiesel is an ideal substitute for fossil diesel as it is biodegradable, nontoxic, renewable, and shows a similar fuel property to fossil diesel. Biodiesel can be produced from the transesterification of vegetable oils (Figure 14a) or the esterification of free fatty acids (FFAs) with alcohols (Figure 14b). Ethanol and methanol are commonly used alcohols.

\begin{tabular}{|c|c|c|c|c|}
\hline slyceride & alcohol & & esters & \\
\hline -R1 & & & R-OOC-R1 & \\
\hline $\mathrm{H} 2-\mathrm{OOC}-\mathrm{R} 2$ & $+3 \mathrm{ROH}$ & $\stackrel{\text { catalyst }}{\longleftrightarrow}$ & R-OOC-R2 & + \\
\hline C-R3 & & & R-OOC-R3 & \\
\hline
\end{tabular}

(a)

$$
\begin{array}{lll}
\text { Fatty acid alcohol } & \text { ester } \\
\mathrm{R} 1-\mathrm{COOH} & +\mathrm{ROH} \stackrel{\text { catalyst }}{\longleftrightarrow} \text { R1-COO-R }+\mathrm{H}_{2} \mathrm{O}
\end{array}
$$

(b)

Figure 14. Reaction equations for biodiesel production: (a) transesterification of glyceride with alcohol; (b) esterification of fatty acid and alcohol.

Various catalysts were explored for biodiesel production. Common homogeneous catalysts include $\mathrm{KOH}, \mathrm{NaOH}, \mathrm{H}_{2} \mathrm{SO}_{4}$, and $\mathrm{NaOMe}$. The recycling of catalysts and the purification of 
products are two problems involved in the use of homogeneous catalysts [172-175]. In contrast, heterogeneous catalysts such as $\mathrm{CaO}, \mathrm{MgO}, \mathrm{ZnO}$, and $\mathrm{CaZrO}_{3}$ can be easily separated from products and reused for several times. However, expensive metal precursors are required for the synthesis of these metal-oxide-based catalysts. Activated biochar is used to prepare catalysts for biodiesel production $[10,11,27,172,176,177]$. These biochar-based catalysts can be classified into two types: (1) solid-acid catalysts and (2) solid-alkali catalysts.

\subsubsection{Solid-Acid Catalysts}

Acid-functionalized biochar catalysts are usually prepared by sulfonating biochar with liquid $\mathrm{H}_{2} \mathrm{SO}_{4}$ or gaseous $\mathrm{SO}_{3}$ (see Section 4.2.1). Examples of their catalytic activity and reusability in biodiesel production are shown in Table 2.

Zeng et al. [178] synthesized a solid-acid catalyst via the sulfonation of partially carbonized peanut shell. The acid strength of the catalyst was stronger than that of HZSM-5 $(\mathrm{Si} / \mathrm{Al}=75)$. When using the catalyst in the transesterification of cottonseed oil with methanol, a conversion of $90.2 \%$ and a good reusability was obtained. Joyleene et al. [179] also prepared a biochar-based solid-acid catalyst via $\mathrm{KOH}$ activation and fuming $\mathrm{H}_{2} \mathrm{SO}_{4}$ sulfonation. They found that the transesterification yield of canola oil was $44.2 \%$ at $150{ }^{\circ} \mathrm{C}$ and $1.52 \mathrm{MPa}$.

Low-grade or waste oils usually contain a large amount of FFAs, which are likely to lower the reaction rate and biodiesel yield. Therefore, the development of catalysts capable of simultaneously catalyzing esterification and transesterification is desirable [180]. Dehkhoda et al. [116] developed a biochar-based solid-acid catalyst for the simultaneous transesterification and esterification of a canola oil and oleic acid mixture at $150{ }^{\circ} \mathrm{C}$ under $1.52 \mathrm{MPa}$. The yield of alkyl ester could be up to $48 \%$ in $3 \mathrm{~h}$ if the proportion of the three reactants was appropriate. The reaction yield decreased by $\sim 8 \%$ upon reusing the catalyst. Shu et al. [181] applied a solid acid derived from the sulfonation of carbonized vegetable oil asphalt for the conversion of a waste vegetable oil rich in free fatty acids to biodiesel. The maximum conversions of triglyceride and FFA reached $80.5 \mathrm{wt} \%$ and $94.8 \mathrm{wt} \%$, respectively, after $4.5 \mathrm{~h}$ at $220{ }^{\circ} \mathrm{C}$, when using a 16.8 molar ratio of methanol to oil and $0.2 \mathrm{wt} \%$ of catalyst to oil. Dawodu et al. [182] reported the conversion of non-edible seed oil, Calophyllum inophyllum, with 15\% FFAs over sulfonated biochar. Under the optimized conditions, the biochar-based catalyst could convert $99.0 \%$ of the oil into biodiesel, which was comparable to conventional acid catalysts. González et al. [119] introduced $-\mathrm{SO}_{3} \mathrm{H}$ groups to biochar using a microwave reactor. The microwave-assisted transesterification and esterification of waste cooking oil over this catalyst achieved a methyl ester yield of $75 \%$ in $15 \mathrm{~min}$.

\section{(1) The Number of Acid Sites}

The number of acid sites on a biochar surface is one of the important parameters that determines its catalytic activity. González et al. [180] observed that an increase in the number of $-\mathrm{SO}_{3} \mathrm{H}$ groups was responsible for a higher biodiesel yield. Shu et al. [181] also believed that a high density of acid sites was one of the factors that led to a high catalytic activity.

In order to load more $-\mathrm{SO}_{3} \mathrm{H}$ groups, biochar with a large surface area and a higher porosity is desirable. Dehkhoda et al. [2] reported that the catalyst with a higher surface area showed a higher transesterification activity among the catalysts with similar acid densities. Kastner et al. [114] also observed the solid-acid catalysts derived from activated biochar had significantly higher activity than that of biochar without activation. In addition to surface area, intrinsic acidic functional groups of biochar also contribute to the total number of acid sites [82]. Both the surface area and the surface functional groups of biochar are affected by its carbonization condition. A high carbonization temperature could increase the surface area of the resultant biochar, but decrease the total acid density [179]. A high carbonization temperature also increases the rigidity of the biochar's carbon sheets, which makes the incorporation of $-\mathrm{SO}_{3} \mathrm{H}$ groups more difficult. That was why Yu et al. [179] observed that the catalyst carbonized at $675^{\circ} \mathrm{C}$ exhibited the highest catalytic performance compared 
to that carbonized at $450{ }^{\circ} \mathrm{C}$ or $875^{\circ} \mathrm{C}$. Therefore, the biochar obtained from incomplete carbonization is usually used for the preparation of biochar-based solid-acid catalysts [178,182].

Apart from the factors of biochar synthesis, the sulfonation methods also influence the number of acid sites. Dehkhoda et al. [2] tested the catalytic performances of two biochar-based solid acids in the transesterification of canola oil. The catalyst treated with fuming $\mathrm{H}_{2} \mathrm{SO}_{4}$ exhibited a much higher activity than that sulfonated with concentrated $\mathrm{H}_{2} \mathrm{SO}_{4}$. Kastner et al. [114] demonstrated that sulfonation of biochar with gaseous $\mathrm{SO}_{3}$ at $23{ }^{\circ} \mathrm{C}$ yielded a higher $-\mathrm{SO}_{3} \mathrm{H}$ density than sulfonation with concentrated $\mathrm{H}_{2} \mathrm{SO}_{4}$ at $100{ }^{\circ} \mathrm{C}$.

Table 2. Biochar-based solid-acid catalysts for biodiesel production.

\begin{tabular}{|c|c|c|c|c|}
\hline $\begin{array}{l}\text { Catalysts (Feedstock, } \\
\text { Synthesis Conditions) }\end{array}$ & $\begin{array}{l}\text { Biodiesel Production } \\
\text { (Feedstock, Reaction } \\
\text { Conditions) }\end{array}$ & Catalytic Activity & Reusability & Reference \\
\hline $\begin{array}{l}\text { Peanut shell, carbonized at } 450 \\
{ }^{\circ} \mathrm{C} \text { for } 15 \mathrm{~h} \text {, sulfonated with } \\
\mathrm{H}_{2} \mathrm{SO}_{4} \text { at } 20{ }^{\circ} \mathrm{C} \text { for } 10 \mathrm{~h}\end{array}$ & $\begin{array}{l}\text { Cottonseed oil and } \\
\text { methanol }(1: 9), 85^{\circ} \mathrm{C}, 2 \mathrm{~h}\end{array}$ & conversion of $90.2 \%$ & $\begin{array}{l}50.3 \% \text { in five } \\
\text { consecutive cycles }\end{array}$ & [178] \\
\hline $\begin{array}{l}\text { Biochar, activated with } \mathrm{KOH} \\
\text { at } 675^{\circ} \mathrm{C} \text {; sulfonated with } \mathrm{SO}_{3} \\
\text { at } 150^{\circ} \mathrm{C} \text { for } 15 \mathrm{~h}\end{array}$ & $\begin{array}{l}\text { Canola oil and methanol (1:15), } \\
150{ }^{\circ} \mathrm{C}, 1.52 \mathrm{Mpa}, 3 \mathrm{~h}\end{array}$ & a reaction yield of $44.2 \%$ & $\begin{array}{l}\text { drop to } 0.9 \% \text {, } \\
\text { poor reusability }\end{array}$ & [179] \\
\hline $\begin{array}{l}\text { Biochar, activated with } \mathrm{KOH} \\
\text { at } 675^{\circ} \mathrm{C} \text {; sulfonated with } \mathrm{SO}_{3} \\
\text { at } 150{ }^{\circ} \mathrm{C} \text { for } 15 \mathrm{~h}\end{array}$ & $\begin{array}{c}\text { Canola oil, oleic acid, and } \\
\text { ethanol (3:1:30), } 150{ }^{\circ} \mathrm{C}, 1.52 \\
\mathrm{MPa}, 3 \mathrm{~h}\end{array}$ & a reaction yield of $48.1 \%$ & $\begin{array}{l}29 \% \text { in the } \\
\text { first recycling }\end{array}$ & [116] \\
\hline $\begin{array}{c}\text { Carbonized vegetable oil } \\
\text { asphalt, sulfonated with } \\
\text { concentrated } \mathrm{H}_{2} \mathrm{SO}_{4} \text { at } 210{ }^{\circ} \mathrm{C} \\
\text { for } 10 \mathrm{~h}\end{array}$ & $\begin{array}{l}\text { A mixture of cottonseed oil } \\
\text { and oleic acid (1:1 in weight), } \\
\text { a molar ratio of methanol/oil } \\
\text { of } 16.8,220^{\circ} \mathrm{C}, 4.5 \mathrm{~h}\end{array}$ & $\begin{array}{l}\text { The conversion of } \\
\text { triglyceride and free } \\
\text { fatty acid were } \\
80.5 \mathrm{wt} \% \text { and } \\
94.8 \mathrm{wt} \% \text {, respectively. }\end{array}$ & $\begin{array}{l}75.5 \% \text { and } 97 \% \text {, } \\
\text { respectively, in } 5 \text { cycles }\end{array}$ & [181] \\
\hline $\begin{array}{l}\text { Glucose, carbonized at } 400{ }^{\circ} \mathrm{C} \\
\text { for } 5 \mathrm{~h} \text {, sulfonated with } \mathrm{H}_{2} \mathrm{SO}_{4} \\
\text { at } 150{ }^{\circ} \mathrm{C} \text { for } 10 \mathrm{~h}\end{array}$ & $\begin{array}{l}\text { Calophyllum inophyllum oil } \\
\text { with free fatty acid of } 15 \% \text {, a } \\
\text { molar ratio of methanol/oil of } \\
30: 1,180^{\circ} \mathrm{C} \text { for } 5 \mathrm{~h}\end{array}$ & Conversion of $99 \%$ & $50.3 \%$ in 5 cycles & [182] \\
\hline $\begin{array}{l}\text { Oat hull, carbonized at } 600{ }^{\circ} \mathrm{C} \\
\text { for } 3 \mathrm{~h} \text {, sulfonated with } \mathrm{H}_{2} \mathrm{SO}_{4} \\
\text { at } 140{ }^{\circ} \mathrm{C} \text { for } 30 \text { min assisted } \\
\text { by microwave }\end{array}$ & $\begin{array}{l}\text { Waste cooking oil and } \\
\text { methanol }(1: 10), 140^{\circ} \mathrm{C}, 30 \\
\text { min, a microwave reactor }\end{array}$ & $\begin{array}{l}\text { A biodiesel yield of } 75 \% \\
\text { in } 15 \mathrm{~min}\end{array}$ & $33 \%$ in 6 cycles & [119] \\
\hline $\begin{array}{l}\text { Coconut shell, carbonized at } \\
422^{\circ} \mathrm{C} \text { for } 4 \mathrm{~h} \text {, sulfonated with } \\
\text { concentrated } \mathrm{H}_{2} \mathrm{SO}_{4} \text { at } 100{ }^{\circ} \mathrm{C} \\
\text { for } 15 \mathrm{~h}\end{array}$ & $\begin{array}{l}\text { Palm oil and methanol (1:30), } \\
\qquad 60^{\circ} \mathrm{C}, 6 \mathrm{~h}\end{array}$ & $\begin{array}{c}\text { A biodiesel } \\
\text { yield of } 88.15 \%\end{array}$ & Not applicable & [183] \\
\hline
\end{tabular}

(2) The Accessibility of Active Sites

Shu et al. [181] and Juan et al. [115] suggested that hydrophilic functional groups present on the biochar surface could facilitate the adsorption of hydrophilic reactants such as ethanol. In addition to the hydrophilic surface, a large pore size allows reactants to have easy access to the active sites. The superiority in the pore morphology of biochar may compensate for the shortcomings of low $-\mathrm{SO}_{3} \mathrm{H}$ density in some cases [112].

(3) The Leaching of $-\mathrm{SO}_{3} \mathrm{H}$

The leaching of $-\mathrm{SO}_{3} \mathrm{H}$ is a main reason for the loss of activity of biochar-based solid acids. A hydrophobic biochar matrix, which prevents the hydration of sulfonic groups, is crucial to the stability of the catalyst. Once $-\mathrm{SO}_{3} \mathrm{H}$ groups are hydrated, they are easily leached as $\mathrm{H}_{2} \mathrm{SO}_{4}$ in the aqueous system $[184,185]$. In addition, the electron-withdrawing $\mathrm{COOH}$ groups present on biochar could also reduce the leaching rate of the $-\mathrm{SO}_{3} \mathrm{H}$ groups by increasing the electron density between the carbon and sulfur atoms $\left(\mathrm{C}-\mathrm{SO}_{3} \mathrm{H}\right)$ [82]. On the contrary, water and FFAs which usually exist in vegetable oils favor the leaching of the active centers [172]. 
(4) Impurities in Crude Oil or Biochar

Impurities present in crude oil, such as chlorophyll and phospholipids, were reported to inhibit the catalytic activity of biochar-based solid acids in the transesterification reaction [27,182]. In order to remove these impurities, a refinement of crude oil prior to the production of biodiesel was suggested [27]. Some inorganic species such as $\mathrm{Cl}$ and $\mathrm{P}$ present in the biochar derived from microalgae also have the potential to impair the catalytic performance of biochar catalysts and lower the quality of the biodiesel produced [27].

\subsubsection{Solid-Alkali Catalysts}

Another type of biochar-based catalyst for biodiesel production is biochar-supported alkali catalysts or biomass-derived solid-alkali catalysts. Their catalytic activity and reusability are listed in Table 3 and are discussed below.

McKay and co-workers $[186,187]$ utilized palm-kernel-shell biochar rich in $\mathrm{CaCO}_{3}$ to prepare a $\mathrm{CaO} /$ biochar catalyst for sunflower-oil metholysis. $\mathrm{CaO}$ was believed to be responsible for the catalytic activity. The conversion of sunflower oil was as high as $99 \%$ at $65^{\circ} \mathrm{C}$, with a methanol-to-oil ratio of 9:1 and a catalyst loading of $3 \mathrm{wt} \%$. The catalyst could be reused for three consecutive cycles with no significant drop in activity. Chakraborty et al. [188] prepared a fly-ash-supported $\mathrm{CaO}$ catalyst with egg shells as the source of $\mathrm{CaO}$. Its catalytic activity for the transesterification of soybean oil was examined. A fatty acid methyl ester (FAME) yield of $96.97 \%$ was obtained under its optimal conditions. Other Ca-rich biomass materials such as bovine bone waste [189] and crab shell [190] were also used to prepare $\mathrm{CaO}$ catalysts through a simple calcination process. These low-cost catalysts exhibited a high biodiesel yield (97\% and 94\%, respectively) and a good reusability, making them an attractive alternative to existing transesterification catalyst systems.

Similarly, $\mathrm{K}_{2} \mathrm{CO}_{3}$ - or $\mathrm{KOH}$-functionalized biochar were also used as catalysts for biodiesel production. Wang et al. [173] synthesized a peat-biochar-supported $\mathrm{K}_{2} \mathrm{CO}_{3}$ catalyst using a wet impregnation method. When the $\mathrm{K}_{2} \mathrm{CO}_{3}$ loading was $30 \%$ and the activation temperature was $600{ }^{\circ} \mathrm{C}$, the catalyst achieved the maximum biodiesel yield, which was $98.6 \%$ for the transesterification of palm oil. The catalytic activity was mainly attributed to its total basicity. Dhawane et al. [191] firstly prepared activated biochar from flamboyant pods, and then loaded $\mathrm{KOH}$ onto the biochar via an impregnation method. When the biochar-supported $\mathrm{KOH}$ catalyst was used for the transesterification of Hevea brasiliensis oil, a biodiesel yield of $89.3 \%$ was achieved.

Table 3. Biochar-based solid-alkali catalysts for biodiesel production. FAME: fatty acid methyl ester.

\begin{tabular}{|c|c|c|c|c|}
\hline $\begin{array}{l}\text { Catalysts (Feedstock, } \\
\text { Synthesis Conditions) }\end{array}$ & $\begin{array}{l}\text { Biodiesel Production } \\
\text { (Feedstock, Reaction } \\
\text { Conditions) }\end{array}$ & $\begin{array}{l}\text { Catalytic } \\
\text { Activity }\end{array}$ & Reusability & References \\
\hline $\begin{array}{l}\text { Palm-kernel-shell biochar, } \\
\text { calcined at } 800{ }^{\circ} \mathrm{C} \text { for } 2 \mathrm{~h} \text { to } \\
\text { form } \mathrm{CaO} / \text { biochar catalyst }\end{array}$ & $\begin{array}{l}\text { Sunflower oil and methanol } \\
(1: 9), 65^{\circ} \mathrm{C}, 300 \mathrm{~min}\end{array}$ & $\begin{array}{l}\text { Conversion } \\
\text { of } 99 \%\end{array}$ & $\begin{array}{l}\text { No significant } \\
\text { activity drop in } 3 \\
\text { cycles }\end{array}$ & {$[186,187]$} \\
\hline $\begin{array}{c}\text { Waste egg shells as } \mathrm{CaO} \\
\text { source, fly ash as support, } \\
\text { wet-impregnation method }\end{array}$ & $\begin{array}{l}\text { Soybean oil and methanol } \\
\qquad(1: 6.9), 70^{\circ} \mathrm{C}, 5 \mathrm{~h}\end{array}$ & $\begin{array}{l}\text { A fame yield } \\
\text { of } 96.97 \%\end{array}$ & $\begin{array}{l}\text { Without major loss } \\
\text { of activity for } 16 \\
\text { cycles }\end{array}$ & [188] \\
\hline $\begin{array}{l}\text { Bovine bone waste, calcined at } \\
\qquad 750{ }^{\circ} \mathrm{C} \text { for } 6 \mathrm{~h}\end{array}$ & $\begin{array}{l}\text { Soybean oil and methanol (1:6), } \\
\qquad 65^{\circ} \mathrm{C}, 3 \mathrm{~h}\end{array}$ & $\begin{array}{l}\text { A fame yield } \\
\text { of } 97 \%\end{array}$ & $\begin{array}{c}>90 \% \text { in four } \\
\text { consecutive runs }\end{array}$ & [189] \\
\hline Crab shell, calcined at $800^{\circ} \mathrm{C}$ & $\begin{array}{l}\text { Karanja oil and methanol (1:8), } \\
65^{\circ} \mathrm{C}, 120 \mathrm{~min}\end{array}$ & $\begin{array}{l}\text { A biodiesel } \\
\text { yield of } 94 \%\end{array}$ & $84 \%$ in the fifth run & [190] \\
\hline $\begin{array}{l}\text { Chicken manure containing } \\
\mathrm{CaCO}_{3} \text {, carbonized at } 350{ }^{\circ} \mathrm{C}\end{array}$ & $\begin{array}{l}\text { Waste cooking oil and methanol } \\
(1: 20 \text { in volume }), 350{ }^{\circ} \mathrm{C}\end{array}$ & $\begin{array}{l}\text { A fame yield } \\
\text { of } 95 \%\end{array}$ & Not applicable & [192] \\
\hline $\begin{array}{l}\text { Pig meat and bone meal, } \\
\text { carbonized at } 650^{\circ} \mathrm{C}, \\
\text { activated by } \mathrm{KOH}, \\
\text { alkalization with } \mathrm{K}_{2} \mathrm{CO}_{3}\end{array}$ & $\begin{array}{l}\text { Palm oil and methanol (1:7), } \\
65^{\circ} \mathrm{C}, 150 \mathrm{~min}\end{array}$ & $\begin{array}{c}\text { A biodiesel } \\
\text { yield of } 98.2 \%\end{array}$ & $\begin{array}{l}84 \% \text { in the } 10 \text { th } \\
\text { cycles }\end{array}$ & {$[193]$} \\
\hline
\end{tabular}




\subsection{Biomass Hydrolysis}

The hydrolysis of lignocellulosic biomass to produce monosaccharides or oligosaccharides is a crucial step for the conversion of biomass to various platform chemicals (e.g., HMF and furfural) and biofuel (e.g., ethanol) [194,195]. Hydrolysis can be catalyzed by Brønsted acids at the temperature range of $90-260^{\circ} \mathrm{C}$ [196]. During this process, protons provided by Brønsted acids attack the oxygen atom of glycosidic linkages, leading to the formation of a cyclic carbonium ion. The cyclic carbonium ion subsequently accepts a hydroxide ion and produces a monosaccharide or an oligosaccharide [196,197].

Common catalysts for biomass hydrolysis include enzymes, liquid mineral acids, and solid acids. The enzymatic hydrolysis is slow and costly. The mineral acids used for biomass hydrolysis are difficult to recycle. In contrast, sulfonated biochar is a promising solid-acid catalyst due to its low cost, high catalytic activity, and good recyclability $[5,112,198]$. The catalytic performances of various biochar-based acid catalysts were summarized in the literature [13]. Some typical examples are shown below.

Jiang et al. [199] prepared a biochar-based solid acid using hydrolyzed corncob residues, and then applied the catalyst to corncob hydrolysis under microwave irradiation. At the temperature range of $110-140{ }^{\circ} \mathrm{C}$, corncobs were effectively hydrolyzed with yields of $34.6 \%$ glucose, $77.3 \%$ xylose, and $100 \%$ arabinose. No substantial decrease in the catalytic activity was observed when the catalyst was reused three times. Li et al. [5] investigated the catalytic performance of a corn-stover-char-based solid acid for the hydrolysis of corn stover, switch grass, and prairie cord grass in comparison with sulfuric acid that had a similar acid concentration. The biochar solid acid exhibited a higher selectivity to glucose, xylose, and total reducing sugar (TSR), as well as a higher glucan conversion, than sulfuric acid. Qi et al. [108] reported that the biochar solid acid derived from the HTC of glucose and sulfosalicylic acid exhibited good catalytic activity for the hydrolysis of cellulose in ionic liquid. A TRS yield of $59.4 \%$ was achieved at $130{ }^{\circ} \mathrm{C}$ for three hours. Moreover, after five recycle runs, the TRS yield remained at $57.4 \%$, indicating the good stability of the solid-acid catalyst. Bai et al. [109] also reported the microwave-assisted conversion of bamboo hemicelluloses into xylo-oligosaccharides (XOS) using sulfonated bamboo char. The maximum XOS yield of $54.7 \mathrm{wt} \%$ was obtained at $150{ }^{\circ} \mathrm{C}$ for $45 \mathrm{~min}$ with a solid-acid-to-water-solvent mass ratio of 1:200. Liu et al. [111] derived sulfonated biochar from lignocellulose residues and concentrated saccharide solution. The catalytic effect of the solid acid on the hydrothermal degradation of corncob was investigated. A furfural yield of $37.75 \%$ and overall corncob conversion rate of $62.00 \%$ was achieved.

Surface functional groups of biochar play an important role in the catalytic performance for biomass hydrolysis. Functional groups that have a strong affinity to beta-1,4-glycosidic bonds, such as $-\mathrm{COOH}$ and phenolic $-\mathrm{OH}$, could promote the accessibility of beta-1,4-glucans, including cellulose, to the $-\mathrm{SO}_{3} \mathrm{H}$ sites, leading to a more efficient hydrolysis $[82,113,200]$. In addition, electrophilic $-\mathrm{COOH}$ groups present on the biochar surface could increase the electron density between the carbon and sulfur atoms, and stabilize the aromatic carbon- $\mathrm{SO}_{3} \mathrm{H}$ bonds so that the leaching of $\mathrm{SO}_{3} \mathrm{H}$ groups is inhibited [82,110].

Pore volumes of biochar also affect the catalytic performance. Ormsby et al. [112] observed that a biochar-based catalyst with a smaller $\mathrm{SO}_{3} \mathrm{H}$ density showed a much higher turnover frequency (TOF) for xylan hydrolysis than sulfonated commercial resin (Amberlyst 15). This was due to the large surface area and appropriate pore volume of the biochar-based catalyst. There was a threshold for pore volume, below which the accessibility to active sites, as well as absorption capacity, was limited.

\subsection{Tar Reduction}

Biomass gasification is a promising technology for the utilization of biomass energy. Tar formation during biomass gasification is a main bottleneck of this technology for several reasons. Firstly, the generation of tar consumes carbon atoms in the feedstock, and hence, reduces the yield of syngas. Secondly, the condensable tar may block downstream pipes or equipment. Lastly, the tar contaminates syngas and adversely affects its application. For example, syngas containing tar would produce 
more aerosols and soot during combustion [201]. Therefore, effective tar reduction is critical to the commercialization of biomass gasification.

The primary constituents of tar are aromatic hydrocarbons including toluene, naphthalene, styrene, phenol, and polycyclic aromatic hydrocarbons (PAHs) [11]. Common methods for tar removal from syngas involve water washing, activated-carbon adsorption, biomass or ceramic material filtration, and catalytic tar cracking. Catalytic tar cracking is considered as the most effective method. Dolomite, olivine, nickel, alkali metals, and noble metals are commonly used catalysts for tar cracking. Recently, the catalytic activities of both biochar itself and biochar-supported active metals were tested [3,91,95,201-203].

\subsubsection{Biochar without Active Metal Loading}

Biochar without active metal loading showed good catalytic activity for tar removal [3,30,204,205]. El-Rub et al. [3] experimentally compared biochar with other common catalysts in terms of their catalytic performances for tar reduction. When naphthalene was used as a model tar compound, the ranking of catalytic activity at $900{ }^{\circ} \mathrm{C}$ was nickel $>$ pine-wood char $>$ dolomite $>$ olivine $>$ silica sand. In other words, biochar exhibited the highest activity for naphthalene conversion among the low-cost catalysts. Mani et al. [204] utilized pine-bark char to catalyze the decomposition of toluene (a model tar compound) in the presence of steam. The toluene conversion could be as high as $94 \%$ at $900{ }^{\circ} \mathrm{C}$. The activation energy of toluene decomposition was $91 \mathrm{~kJ} / \mathrm{mol}$ for the biochar catalyst, comparable to those for synthetic catalysts (e.g., $80 \mathrm{~kJ} / \mathrm{mol}$ for Ni/mayenite). However, the biochar catalyst showed a lower tar removal rate than olivine and nickel catalysts. Luo et al. [30] reported that a rice-straw-derived biochar catalyst could achieve a tar removal efficiency of $94.03 \%$ after an 8 -min reaction at $600{ }^{\circ} \mathrm{C}$ under microwave heating. They believed that the catalytic performance of the biochar catalyst was comparable to conventional technologies at $700-900{ }^{\circ} \mathrm{C}$.

The catalytic activity of biochar for tar removal is affected by its mineral content, surface area, and surface functional groups. The inorganic species present in biochar play an important role in the catalytic behavior, despite their quantity being small. Klinghoffer et al. [45] demonstrated that $>95 \%$ removal of $\mathrm{Ca}, \mathrm{K}, \mathrm{P}$, and $\mathrm{Mg}$ from the char led to an $18 \%$ decrease in the decomposition of methane. An elevated temperature would cause the combination of inorganics with oxygen to form metal oxides on the surface of the biochar, which also caused a $40 \%$ loss in the catalytic activity. The surface area of biochar also affects its catalytic activity. Bhandari et al. [95] reported that switchgrass biochar activated with $\mathrm{KOH}$ exhibited a higher toluene removal efficiency than that without activation $(92 \%$ vs. $69 \%$ ). They attributed the better catalytic performance to the higher surface area, larger pore diameter, and larger pore volume caused by activation. Alkaline oxygenated groups (e.g., carbonylic, quinonyl, and pyrone structures) that remain attached on biochar at the tar-cracking temperature may also contribute to the catalytic activity [45]. In contrast, acidic groups (e.g., carboxylic and lactones), which disappear at an elevated temperature, are not likely to participate in the cracking reactions [45].

\subsubsection{Biochar-Supported Active Metals}

Loading biochar with active metals (e.g., $\mathrm{Ni}$ and $\mathrm{Fe}$ ) can achieve a higher catalytic activity for tar decomposition than using biochar alone. Kastner et al. [204,206] reported the loading of Fe on biochar lowered the activation energy of toluene reformation from $91 \mathrm{~kJ} / \mathrm{mol}$ to $48 \mathrm{~kJ} / \mathrm{mol}$. At $800{ }^{\circ} \mathrm{C}$ for the catalyst loaded with $13 \% \mathrm{Fe}$, the conversion of toluene approached $100 \%$. If maintaining the reaction stream for four days, a mean toluene conversion of $91 \%$ was obtained. Wang et al. [202] prepared an $\mathrm{Ni}$ /char catalyst by mechanically mixing $\mathrm{NiO}$ and biochar particles followed by in situ reduction. This catalyst could remove more than $96 \%$ of the tar in syngas under optimal conditions, while the biochar without Ni could only remove $90 \%$ of the tar. Shen et al. [153] prepared a biochar-supported $\mathrm{Ni} / \mathrm{Fe}$ catalyst by impregnating rich husk char in metal salts followed by a pyrolysis process. Under the optimized conditions, the conversion efficiency of condensable tar via in situ dry reforming over the biochar-supported $\mathrm{Ni} / \mathrm{Fe}$ catalyst could reach about $92.3 \%$, much higher than that over the biochar 
itself (42\%). Shen et al. [201] also prepared a rice-husk char supported (HCS) Ni catalyst via a facile one-step method (see Section 4.4.1). The HCS Ni catalyst exhibited considerable catalytic activity on tar reformation, even at a relatively lower temperature $\left(500{ }^{\circ} \mathrm{C}\right)$. When the reaction temperature was at $700{ }^{\circ} \mathrm{C}$, the efficiency of tar reformation could be up to $99.8 \%$, and kept almost unchanged after five cycles. Richardson et al. [144] also demonstrated that the Ni NPs in situ generated on biochar via the one-step method exhibited a higher catalytic activity for aromatic tar conversion than pre-formed $\mathrm{Ni}$ NPs that were inserted into the biomass prior to pyrolysis.

For metal/biochar catalysts, biochar has multiple functions [6,153]. Firstly, biochar acts as a support to disperse and stabilize the active metals. Secondly, biochar works as an intermediate reductant to convert metal oxides (normally from the decomposition of metal salts) to a metallic state, which enhances the tar conversion. Thirdly, the biochar itself has some catalytic activity owing to the presence of inorganics [45]. Lastly, biochar also plays the role of absorbent for tar components if its surface is tuned to be hydrophobic.

\section{Conclusions and Perspectives}

\subsection{Conclusions}

This paper reviewed the synthesis, characteristics, and modification of biochar, as well as the application of biochar-based catalysts in three important processes for biofuel production.

Conventionally, biochar is synthesized on various pyrolysis platforms. The properties of biochar are affected by the composition and morphology of biomass feedstock, as well as pyrolysis conditions, especially temperature. In recent times, hydrothermal carbonization (HTC), which is performed at $180-250^{\circ} \mathrm{C}$ in the presence of water, was developed for biochar production. Compared to pyrolysis, HTC has advantages when processing high-moisture biomass and producing spherical biochar particles, but the feedstock for HTC is presently limited by simple carbohydrates. The resultant biochar from either pyrolysis or HTC exhibits typical features, which are the presence of inorganics, surface functional groups, and local crystalline structures made up of highly conjugated aromatic sheets. Various strategies are adopted to modify biochar so that it is more capable of being a catalyst or catalyst support. The surface area and porosity of biochar can be increased via physical activation or chemical activation. The biochar surface can be functionalized via surface sulfonation, surface amination, or surface oxidation. The physiochemical properties can also be finely tuned by in situ heteroatom doping. In addition, forming composites with other materials, such as metals, metal carbides, and nanostructured carbon materials, is also a common method to make use of biochar as a catalyst material. Through these modification strategies, a series of biochar-based catalysts were prepared and tested in biorefinery processes. Sulfonated biochar showed good catalytic performance for biomass hydrolysis and biodiesel production. Biodiesel production can also be catalyzed by biochar-derived or -supported solid-alkali catalysts. Biochar alone and biochar-supported metal catalysts are potential catalysts for tar reduction, an important step to obtaining clean syngas from biomass gasification.

In summary, biochar-based catalysts have several advantages. Firstly, the production of biochar is cheap and convenient owing to its renewable feedstock and well-developed synthesis techniques. Secondly, various strategies were developed to tune the physicochemical properties of biochar according to its specific purpose. Lastly, some intrinsic features of biochar, such as surface functional groups and the presence of inorganic species, may be favorable for its role as a catalyst or catalyst support. Therefore, biochar-based catalysts are a promising alternative to expensive or non-renewable traditional catalysts. The use of biochar-based catalysts in biofuel production represents a more sustainable and more integrated biorefinery scheme. 


\subsection{Perspectives}

Biochar-based catalysts are still at the stage of laboratory research. For an industrial application in the future, purpose-driven synthesis and modification are required. This objective could be realized by mechanism studies. Firstly, the relationship between the catalytic activity and physicochemical properties of biochar needs to be deeply understood. This can be achieved by combining advanced characterization techniques for materials and theoretical modeling for catalytic mechanisms. Secondly, it is also important to reveal the influences of synthesis conditions and feedstock on the properties of resultant biochar. The complex composition of biomass and complicated formation mechanism of biochar make this work quite difficult. Advanced characterization techniques, especially those for online process monitoring from several aspects (e.g., thermogravimetric analysis/Fourier-transform infrared spectroscopy/mass spectrometry (TGA/FTIR/MS) and pyrolysis/gas chromatography/mass spectrometry (Py/GC/MS), are likely to play a crucial role.

As for the aspect of process optimization, much more attention needs to be paid to the use of catalysts in biochar synthesis. Although some inorganic species present in biomass feedstock show catalytic activity for pyrolysis, their autocatalysis alone is insufficient. It is necessary to develop catalysts that can achieve one of the following goals at least: (1) to produce biochar more efficiently by reducing reaction temperature or residence time; (2) to be able to prepare biochar with desired properties in one pot instead of synthesis and modification as two steps. Hopefully, in the future, a catalyst can convert biomass into biochar with the desired functional groups and porous structure in one step, and later combine with the biochar to directly produce biochar-supported catalysts. Furthermore, the industrial production of biochar-based catalysts could be closely combined with the production of biofuels and biochemicals in a biomass refinery, so that the process of biomass utilization is more integrated and more sustainable.

Author Contributions: F.C. and X.L. collected the related literature; X.L. constructed the outline of the review and provided comments; F.C. wrote the paper.

Funding: This research was funded by the National Natural Science Foundation of China [grant number 51676098], the Natural Science Foundation of Jiangsu Province [grant numbers BK20160822 and BK20170095], and the Fundamental Research Funds for the Central Universities [grant number 30917011327]. The APC was funded by the Natural Science Foundation of Jiangsu Province [grant number BK20160822].

Acknowledgments: The authors gratefully acknowledge the financial supports from the National Natural Science Foundation of China under contract No. 51676098, the Natural Science Foundation of Jiangsu Province under contract No. BK20160822 and BK20170095, and the Fundamental Research Funds for the Central Universities under contract No. 30917011327.

Conflicts of Interest: The authors declare no conflict of interest. The founding sponsors had no role in the design of the study; in the collection, analyses, or interpretation of data; in the writing of the manuscript, and in the decision to publish the results. This manuscript has not been published or presented elsewhere in part or entirety and it is not under consideration by another journal. All the authors approved the manuscript and agreed to its submission to your esteemed journal.

\section{References}

1. Lin, Y.C.; Huber, G.W. The critical role of heterogeneous catalysis in lignocellulosic biomass conversion. Energy Environ. Sci. 2009, 2, 68-80. [CrossRef]

2. Dehkhoda, A.M.; West, A.H.; Ellis, N. Biochar based solid acid catalyst for biodiesel production. Appl. Catal. A 2010, 382, 197-204. [CrossRef]

3. Abu El-Rub, Z.; Bramer, E.A.; Brem, G. Experimental comparison of biomass chars with other catalysts for tar reduction. Fuel 2008, 87, 2243-2252. [CrossRef]

4. Nguyen, H.K.D.; Pham, V.V.; Do, H.T. Preparation of Ni/biochar catalyst for hydrotreating of bio-oil from microalgae biomass. Catal. Lett. 2016, 146, 2381-2391. [CrossRef]

5. Li, S.; Gu, Z.; Bjornson, B.E.; Muthukumarappan, A. Biochar based solid acid catalyst hydrolyze biomass. Chem. Eng. J. 2013, 1, 1174-1181. [CrossRef] 
6. Qian, K.; Kumar, A.; Zhang, H.; Bellmer, D.; Huhnke, R. Recent advances in utilization of biochar. Renew. Sustain. Energy Rev. 2015, 42, 1055-1064. [CrossRef]

7. Li, J.; Dai, J.; Liu, G.; Zhang, H.; Gao, Z.; Fu, J.; He, Y.; Huang, Y. Biochar from microwave pyrolysis of biomass: A review. Biomass Bioenergy 2016, 94, 228-244. [CrossRef]

8. $\quad$ Lam, S.S.; Liew, R.K.; Wong, Y.M.; Yek, P.N.Y.; Ma, N.L.; Lee, C.L.; Chase, H.A. Microwave-assisted pyrolysis with chemical activation, an innovative method to convert orange peel into activated carbon with improved properties as dye adsorbent. J. Clean. Prod. 2017, 162, 1376-1387. [CrossRef]

9. Titirici, M.M.; White, R.J.; Falco, C.; Sevilla, M. Black perspectives for a green future: Hydrothermal carbons for environment protection and energy storage. Energy Environ. Sci. 2012, 5, 6796-6822. [CrossRef]

10. Cha, J.S.; Park, S.H.; Jung, S.C.; Ryu, C.; Jeon, J.K.; Shin, M.C.; Park, Y.K. Production and utilization of biochar: A review. J. Ind. Eng. Chem. 2016, 40, 1-15. [CrossRef]

11. Lee, J.; Kim, K.-H.; Kwon, E.E. Biochar as a catalyst. Renew. Sustain. Energy Rev. 2017, 77, 70-79. [CrossRef]

12. Hervy, M.; Berhanu, S.; Weiss-Hortala, E.; Chesnaud, A.; Gerente, C.; Villot, A.; Minh, D.P.; Thorel, A.; Le Coq, L.; Nzihou, A. Multi-scale characterisation of chars mineral species for tar cracking. Fuel 2017, 189, 88-97. [CrossRef]

13. Cao, X.; Sun, S.; Sun, R. Application of biochar-based catalysts in biomass upgrading: A review. RSC Adv. 2017, 7, 48793-48805. [CrossRef]

14. Xiong, X.; Yu, I.K.M.; Cao, L.; Tsang, D.C.W.; Zhang, S.; Ok, Y.S. A review of biochar-based catalysts for chemical synthesis, biofuel production, and pollution control. Bioresour. Technol. 2017, 246, 254-270. [CrossRef] [PubMed]

15. Liu, W.J.; Jiang, H.; Yu, H.Q. Development of biochar-based functional materials: Toward a sustainable platform carbon material. Chem. Rev. 2015, 115, 12251-12285. [CrossRef] [PubMed]

16. Tan, X.F.; Liu, Y.G.; Gu, Y.L.; Xu, Y.; Zeng, G.M.; Hu, X.J.; Liu, S.B.; Wang, X.; Liu, S.M.; Li, J. Biochar-based nano-composites for the decontamination of wastewater: A review. Bioresour. Technol. 2016, 212, 318-333. [CrossRef] [PubMed]

17. Cheng, B.H.; Zeng, R.J.; Jiang, H. Recent developments of post-modification of biochar for electrochemical energy storage. Bioresour. Technol. 2017, 246, 224-233. [CrossRef] [PubMed]

18. Dong, Q.; Li, H.; Niu, M.; Luo, C.; Zhang, J.; Qi, B.; Li, X.; Zhong, W. Microwave pyrolysis of moso bamboo for syngas production and bio-oil upgrading over bamboo-based biochar catalyst. Bioresour. Technol. 2018, 266, 284-290. [CrossRef] [PubMed]

19. Singh, S.; Nahil, M.A.; Sun, X.; Wu, C.; Chen, J.; Shen, B.; Williams, P.T. Novel application of cotton stalk as a waste derived catalyst in the low temperature SCR-deNO ${ }_{x}$ process. Fuel 2013, 105, 585-594. [CrossRef]

20. Shen, B.; Chen, J.; Yue, S.; Li, G. A comparative study of modified cotton biochar and activated carbon based catalysts in low temperature SCR. Fuel 2015, 156, 47-53. [CrossRef]

21. Kastner, J.R.; Miller, J.; Kolar, P.; Das, K.C. Catalytic ozonation of ammonia using biomass char and wood fly ash. Chemosphere 2009, 75, 739-744. [CrossRef] [PubMed]

22. Da, Z.L.; Niu, X.H.; Li, X.; Zhang, W.C.; He, Y.F.; Pan, J.M.; Qiu, F.X.; Yan, Y.S. From moldy orange waste to natural reductant and catalyst support: Active palladium/biomass-derived carbonaceous hybrids for promoted methanol electro-oxidation. ChemElectroChem 2017, 4, 1372-1377. [CrossRef]

23. Jia, Y.; Feng, H.; Shen, D.; Zhou, Y.; Chen, T.; Wang, M.; Chen, W.; Ge, Z.; Huang, L.; Zheng, S. High-performance microbial fuel cell anodes obtained from sewage sludge mixed with fly ash. J. Hazard. Mater. 2018, 354, 27-32. [CrossRef] [PubMed]

24. Kim, J.R.; Kan, E. Heterogeneous photocatalytic degradation of sulfamethoxazole in water using a biochar-supported $\mathrm{TiO}_{2}$ photocatalyst. J. Environ. Manag. 2016, 180, 94-101. [CrossRef] [PubMed]

25. Liu, X.Q.; Chen, W.J.; Jiang, H. Facile synthesis of $\mathrm{Ag} / \mathrm{Ag}_{3} \mathrm{PO}_{4} / \mathrm{AMB}$ composite with improved photocatalytic performance. Chem. Eng. J. 2017, 308, 889-896. [CrossRef]

26. Li, P.J.; Lin, K.R.; Fang, Z.Q.; Wang, K.M. Enhanced nitrate removal by novel bimetallic Fe/Ni nanoparticles supported on biochar. J. Clean. Prod. 2017, 151, 21-33. [CrossRef]

27. Dong, T.; Gao, D.; Miao, C.; Yu, X.; Degan, C.; Garcia-Pérez, M.; Rasco, B.; Sablani, S.S.; Chen, S. Two-step microalgal biodiesel production using acidic catalyst generated from pyrolysis-derived bio-char. Energy Convers. Manag. 2015, 105, 1389-1396. [CrossRef] 
28. Ren, S.; Lei, H.; Wang, L.; Bu, Q.; Chen, S.; Wu, J. Hydrocarbon and hydrogen-rich syngas production by biomass catalytic pyrolysis and bio-oil upgrading over biochar catalysts. RSC Adv. 2014, 4, 10731-10737. [CrossRef]

29. Shen, Y. Chars as carbonaceous adsorbents/catalysts for tar elimination during biomass pyrolysis or gasification. Renew. Sustain. Energy Rev. 2015, 43, 281-295. [CrossRef]

30. Luo, H.; Bao, L.; Wang, H.; Kong, L.; Sun, Y. Microwave-assisted in-situ elimination of primary tars over biochar: Low temperature behaviours and mechanistic insights. Bioresour. Technol. 2018, 267, 333-340. [CrossRef] [PubMed]

31. Yan, Q.; Wan, C.; Liu, J.; Gao, J.; Yu, F.; Zhang, J.; Cai, Z. Iron nanoparticles in situ encapsulated in biochar-based carbon as an effective catalyst for the conversion of biomass-derived syngas to liquid hydrocarbons. Green Chem. 2013, 15, 1631-1640. [CrossRef]

32. DeSisto, W.J.; Hill, N.; Beis, S.H.; Mukkamala, S.; Joseph, J.; Baker, C.; Ong, T.H.; Stemmler, E.A.; Wheeler, M.C.; Frederick, B.G. Fast pyrolysis of pine sawdust in a fluidized-bed reactor. Energy Fuels 2010, 24, 2642-2651. [CrossRef]

33. Brewer, C.E.; Schmidt-Rohr, K.; Satrio, J.A.; Brown, R.C. Characterization of biochar from fast pyrolysis and gasification systems. Environ. Prog. Sustain. Energy 2009, 28, 386-396. [CrossRef]

34. Dutta, B.; Raghavan, G.S.V.; Ngadi, M. Surface characterization and classification of slow and fast pyrolyzed biochar using novel methods of pycnometry and hyperspectral imaging. J. Wood Chem. Technol. 2012, 32, 105-120. [CrossRef]

35. Antal, M.J.; Gronli, M. The art, science, and technology of charcoal production. Ind. Eng. Chem. Res. 2003, 42, 1619-1640. [CrossRef]

36. Brendova, K.; Szakova, J.; Lhotka, M.; Krulikovska, T.; Puncochar, M.; Tlustos, P. Biochar physicochemical parameters as a result of feedstock material and pyrolysis temperature: Predictable for the fate of biochar in soil? Environ. Geochem. Health 2017, 39, 1381-1395. [CrossRef] [PubMed]

37. Zhao, L.; Cao, X.; Masek, O.; Zimmerman, A. Heterogeneity of biochar properties as a function of feedstock sources and production temperatures. J. Hazard. Mater. 2013, 256, 1-9. [CrossRef] [PubMed]

38. Yang, H.; Yan, R.; Chen, H.; Lee, D.H.; Zheng, C. Characteristics of hemicellulose, cellulose and lignin pyrolysis. Fuel 2007, 86, 1781-1788. [CrossRef]

39. Thompson, E.; Danks, A.E.; Bourgeois, L.; Schnepp, Z. Iron-catalyzed graphitization of biomass. Green Chem. 2015, 17, 551-556. [CrossRef]

40. Xue, G.; Liu, K.; Chen, Q.; Yang, P.; Li, J.; Ding, T.; Duan, J.; Qi, B.; Zhou, J. Robust and low-cost flame-treated wood for high-performance solar steam generation. ACS Appl. Mater. Interfaces 2017, 9, 15052-15057. [CrossRef] [PubMed]

41. Li, Y.; Zhang, Q.; Zhang, J.; Jin, L.; Zhao, X.; Xu, T. A top-down approach for fabricating free-standing bio-carbon supercapacitor electrodes with a hierarchical structure. Sci. Rep. 2015, 5, 14155. [CrossRef] [PubMed]

42. Yao, H.; Zheng, G.; Li, W.; McDowell, M.T.; Seh, Z.; Liu, N.; Lu, Z.; Cui, Y. Crab shells as sustainable templates from nature for nanostructured battery electrodes. Nano Lett. 2013, 13, 3385-3390. [CrossRef] [PubMed]

43. Abu Bakar, M.S.; Titiloye, J.O. Catalytic pyrolysis of rice husk for bio-oil production. J. Anal. Appl. Pyrolysis 2013, 103, 362-368. [CrossRef]

44. Nowakowski, D.J.; Jones, J.M.; Brydson, R.M.D.; Ross, A.B. Potassium catalysis in the pyrolysis behaviour of short rotation willow coppice. Fuel 2007, 86, 2389-2402. [CrossRef]

45. Klinghoffer, N.B.; Castaldi, M.J.; Nzihou, A. Influence of char composition and inorganics on catalytic activity of char from biomass gasification. Fuel 2015, 157, 37-47. [CrossRef]

46. McBeath, A.V.; Wurster, C.M.; Bird, M.I. Influence of feedstock properties and pyrolysis conditions on biochar carbon stability as determined by hydrogen pyrolysis. Biomass Bioenergy 2015, 73, 155-173. [CrossRef]

47. Yao, D.; Hu, Q.; Wang, D.; Yang, H.; Wu, C.; Wang, X.; Chen, H. Hydrogen production from biomass gasification using biochar as a catalyst/support. Bioresour. Technol. 2016, 216, 159-164. [CrossRef] [PubMed]

48. Uchimiya, M.; Wartelle, L.H.; Klasson, K.T.; Fortier, C.A.; Lima, I.M. Influence of pyrolysis temperature on biochar property and function as a heavy metal sorbent in soil. J. Agric. Food. Chem. 2011, 59, 2501-2510. [CrossRef] [PubMed]

49. Zhang, J.; Liu, J.; Liu, R. Effects of pyrolysis temperature and heating time on biochar obtained from the pyrolysis of straw and lignosulfonate. Bioresour. Technol. 2015, 176, 288-291. [CrossRef] [PubMed] 
50. Zhao, B.; O’Connor, D.; Zhang, J.; Peng, T.; Shen, Z.; Tsang, D.C.W.; Hou, D. Effect of pyrolysis temperature, heating rate, and residence time on rapeseed stem derived biochar. J. Clean. Prod. 2018, 174, 977-987. [CrossRef]

51. Muradov, N.; Fidalgo, B.; Gujar, A.C.; Garceau, N.; T-Raissi, A. Production and characterization of lemna minor bio-char and its catalytic application for biogas reforming. Biomass Bioenergy 2012, 42, 123-131. [CrossRef]

52. Keiluweit, M.; Nico, P.S.; Johnson, M.G.; Kleber, M. Dynamic molecular structure of plant biomass-derived black carbon (biochar). Environ. Sci. Technol. 2010, 44, 1247-1253. [CrossRef] [PubMed]

53. Román, S.; Nabais, J.M.V.; Laginhas, C.; Ledesma, B.; González, J.F. Hydrothermal carbonization as an effective way of densifying the energy content of biomass. Fuel Process. Technol. 2012, 103, 78-83. [CrossRef]

54. Xiao, L.P.; Shi, Z.J.; Xu, F.; Sun, R.C. Hydrothermal carbonization of lignocellulosic biomass. Bioresour. Technol. 2012, 118, 619-623. [CrossRef] [PubMed]

55. Hu, B.; Wang, K.; Wu, L.; Yu, S.H.; Antonietti, M.; Titirici, M.M. Engineering carbon materials from the hydrothermal carbonization process of biomass. Adv. Mater. 2010, 22, 813-828. [CrossRef] [PubMed]

56. De Caprariis, B.; De Filippis, P.; Petrullo, A.; Scarsella, M. Hydrothermal liquefaction of biomass: Influence of temperature and biomass composition on the bio-oil production. Fuel 2017, 208, 618-625. [CrossRef]

57. Tekin, K.; Karagoz, S.; Bektas, S. Hydrothermal liquefaction of beech wood using a natural calcium borate mineral. J. Supercrit. Fluids 2012, 72, 134-139. [CrossRef]

58. He, C.; Chen, C.L.; Giannis, A.; Yang, Y.; Wang, J.Y. Hydrothermal gasification of sewage sludge and model compounds for renewable hydrogen production: A review. Renew. Sustain. Energy Rev. 2014, 39, 1127-1142. [CrossRef]

59. Kong, L.; Li, G.; Zhang, B.; He, W.; Wang, H. Hydrogen production from biomass wastes by hydrothermal gasification. Energy Source Part A 2008, 30, 1166-1178. [CrossRef]

60. Kruse, A. Hydrothermal biomass gasification. J. Supercrit. Fluids 2009, 47, 391-399. [CrossRef]

61. Poerschmann, J.; Baskyr, I.; Weiner, B.; Koehler, R.; Wedwitschka, H.; Kopinke, F.D. Hydrothermal carbonization of olive mill wastewater. Bioresour. Technol. 2013, 133, 581-588. [CrossRef] [PubMed]

62. Kruse, A.; Funke, A.; Titirici, M.-M. Hydrothermal conversion of biomass to fuels and energetic materials. Curr. Opin. Chem. Biol. 2013, 17, 515-521. [CrossRef] [PubMed]

63. Sabio, E.; Álvarez-Murillo, A.; Román, S.; Ledesma, B. Conversion of tomato-peel waste into solid fuel by hydrothermal carbonization: Influence of the processing variables. Waste Manag. 2016, 47, 122-132. [CrossRef] [PubMed]

64. Kambo, H.S.; Dutta, A. A comparative review of biochar and hydrochar in terms of production, physico-chemical properties and applications. Renew. Sustain. Energy Rev. 2015, 45, 359-378. [CrossRef]

65. Licursi, D.; Antonetti, C.; Fulignati, S.; Vitolo, S.; Puccini, M.; Ribechini, E.; Bernazzani, L.; Galletti, A.M.R. In-depth characterization of valuable char obtained from hydrothermal conversion of hazelnut shells to levulinic acid. Bioresour. Technol. 2017, 244, 880-888. [CrossRef] [PubMed]

66. Kim, D.; Lee, K.; Park, K.Y. Upgrading the characteristics of biochar from cellulose, lignin, and xylan for solid biofuel production from biomass by hydrothermal carbonization. J. Ind. Eng. Chem. 2016, 42, 95-100. [CrossRef]

67. Cao, X.; Peng, X.; Sun, S.; Zhong, L.; Sun, R. Hydrothermal conversion of bamboo: Identification and distribution of the components in solid residue, water-soluble and acetone-soluble fractions. J. Agric. Food. Chem. 2014, 62, 12360-12365. [CrossRef] [PubMed]

68. Sasaki, M.; Adschiri, T.; Arai, K. Fractionation of sugarcane bagasse by hydrothermal treatment. Bioresour. Technol. 2003, 86, 301-304. [CrossRef]

69. Bilgic, E.; Yaman, S.; Haykiri-Acma, H.; Kucukbayrak, S. Is torrefaction of polysaccharides-rich biomass equivalent to carbonization of lignin-rich biomass? Bioresour. Technol. 2016, 200, 201-207. [CrossRef] [PubMed]

70. Falco, C.; Baccile, N.; Titirici, M.-M. Morphological and structural differences between glucose, cellulose and lignocellulosic biomass derived hydrothermal carbons. Green Chem. 2011, 13, 3273-3281. [CrossRef]

71. Chheda, J.N.; Roman-Leshkov, Y.; Dumesic, J.A. Production of 5-hydroxymethylfurfural and furfural by dehydration of biomass-derived mono- and poly-saccharides. Green Chem. 2007, 9, 342-350. [CrossRef]

72. Titirici, M.-M.; Antonietti, M.; Baccile, N. Hydrothermal carbon from biomass: A comparison of the local structure from poly- to monosaccharides and pentoses/hexoses. Green Chem. 2008, 10, 1204-1212. [CrossRef] 
73. Berge, N.D.; Ro, K.S.; Mao, J.; Flora, J.R.V.; Chappell, M.A.; Bae, S. Hydrothermal carbonization of municipal waste streams. Environ. Sci. Technol. 2011, 45, 5696-5703. [CrossRef] [PubMed]

74. Huggins, T.; Wang, H.; Kearns, J.; Jenkins, P.; Ren, Z.J. Biochar as a sustainable electrode material for electricity production in microbial fuel cells. Bioresour. Technol. 2014, 157, 114-119. [CrossRef] [PubMed]

75. Zhao, L.; Fan, L.Z.; Zhou, M.Q.; Guan, H.; Qiao, S.; Antonietti, M.; Titirici, M.M. Nitrogen-containing hydrothermal carbons with superior performance in supercapacitors. Adv. Mater. 2010, 22, 5202-5206. [CrossRef] [PubMed]

76. Brown, T.R.; Wright, M.M.; Brown, R.C. Estimating profitability of two biochar production scenarios: Slow pyrolysis vs fast pyrolysis. Biofuels Bioprod. Biorefining 2011, 5, 54-68. [CrossRef]

77. Mullen, C.A.; Boateng, A.A.; Goldberg, N.M.; Lima, I.M.; Laird, D.A.; Hicks, K.B. Bio-oil and bio-char production from corn cobs and stover by fast pyrolysis. Biomass Bioenergy 2010, 34, 67-74. [CrossRef]

78. Lua, A.C.; Yang, T.; Guo, J. Effects of pyrolysis conditions on the properties of activated carbons prepared from pistachio-nut shells. J. Anal. Appl. Pyrolysis 2004, 72, 279-287. [CrossRef]

79. Liu, S.S.; Wang, M.F.; Sun, X.Y.; Xu, N.; Liu, J.; Wang, Y.Z.; Qian, T.; Yan, C.L. Facilitated oxygen chemisorption in heteroatom-doped carbon for improved oxygen reaction activity in all-solid-state zinc-air batteries. Adv. Mater. 2018, 30, 1704898. [CrossRef] [PubMed]

80. Ren, Q.; Wang, H.; Lu, X.F.; Tong, Y.X.; Li, G.R. Recent progress on MOF-derived heteroatom-doped carbon-based electrocatalysts for oxygen reduction reaction. Adv. Sci. 2018, 5, 1700515. [CrossRef] [PubMed]

81. Son, E.B.; Poo, K.M.; Mohamed, H.O.; Choi, Y.J.; Cho, W.C.; Chae, K.J. A novel approach to developing a reusable marine macro-algae adsorbent with chitosan and ferric oxide for simultaneous efficient heavy metal removal and easy magnetic separation. Bioresour. Technol. 2018, 259, 381-387. [CrossRef] [PubMed]

82. Kitano, M.; Yamaguchi, D.; Suganuma, S.; Nakajima, K.; Kato, H.; Hayashi, S.; Hara, M. Adsorption-enhanced hydrolysis of beta-1,4-glucan on graphene-based amorphous carbon bearing $\mathrm{SO}_{3} \mathrm{H}, \mathrm{COOH}$, and $\mathrm{OH}$ groups. Langmuir 2009, 25, 5068-5075. [CrossRef] [PubMed]

83. Hagen, J. Heterogeneous catalysis: Fundamentals. In Industrial Catalysis; John Wiley and Sons, Inc.: Hoboken, NJ, USA, 2015; pp. 99-100, ISBN 9783527684625.

84. Duan, X.H.; Srinivasakannan, C.; Peng, J.H.; Zhang, L.B.; Zhang, Z.Y. Comparison of activated carbon prepared from jatropha hull by conventional heating and microwave heating. Biomass Bioenergy 2011, 35, 3920-3926.

85. Alvarez, J.; Lopez, G.; Amutio, M.; Bilbao, J.; Olazar, M. Upgrading the rice husk char obtained by flash pyrolysis for the production of amorphous silica and high quality activated carbon. Bioresour. Technol. 2014, 170, 132-137. [CrossRef] [PubMed]

86. Yang, K.; Peng, J.; Srinivasakannan, C.; Zhang, L.; Xia, H.; Duan, X. Preparation of high surface area activated carbon from coconut shells using microwave heating. Bioresour. Technol. 2010, 101, 6163-6169. [CrossRef] [PubMed]

87. Cha, J.S.; Choi, J.C.; Ko, J.H.; Park, Y.K.; Park, S.H.; Jeong, K.E.; Kim, S.S.; Jeon, J.K. The low-temperature scr of no over rice straw and sewage sludge derived char. Chem. Eng. J. 2010, 156, 321-327. [CrossRef]

88. Ros, A.; Lillo-Ródenas, M.A.; Fuente, E.; Montes-Morán, M.A.; Martín, M.J.; Linares-Solano, A. High surface area materials prepared from sewage sludge-based precursors. Chemosphere 2006, 65, 132-140. [CrossRef] [PubMed]

89. González, J.F.; Román, S.; Encinar, J.M.; Martínez, G. Pyrolysis of various biomass residues and char utilization for the production of activated carbons. J. Anal. Appl. Pyrolysis 2009, 85, 134-141. [CrossRef]

90. Angın, D.; Altintig, E.; Köse, T.E. Influence of process parameters on the surface and chemical properties of activated carbon obtained from biochar by chemical activation. Bioresour. Technol. 2013, 148, 542-549. [CrossRef] [PubMed]

91. Jin, H.; Capareda, S.; Chang, Z.; Gao, J.; Xu, Y.; Zhang, J. Biochar pyrolytically produced from municipal solid wastes for aqueous as(v) removal: Adsorption property and its improvement with koh activation. Bioresour. Technol. 2014, 169, 622-629. [CrossRef] [PubMed]

92. Dehkhoda, A.M.; Ellis, N.; Gyenge, E. Electrosorption on activated biochar: Effect of thermo-chemical activation treatment on the electric double layer capacitance. J. Appl. Electrochem. 2014, 44, 141-157. [CrossRef]

93. Tay, T.; Ucar, S.; Karagöz, S. Preparation and characterization of activated carbon from waste biomass. J. Hazard. Mater. 2009, 165, 481-485. [CrossRef] [PubMed] 
94. Gratuito, M.K.B.; Panyathanmaporn, T.; Chumnanklang, R.A.; Sirinuntawittaya, N.; Dutta, A. Production of activated carbon from coconut shell: Optimization using response surface methodology. Bioresour. Technol. 2008, 99, 4887-4895. [CrossRef] [PubMed]

95. Bhandari, P.N.; Kumar, A.; Bellmer, D.D.; Huhnke, R.L. Synthesis and evaluation of biochar-derived catalysts for removal of toluene (model tar) from biomass-generated producer gas. Renew. Energy 2014, 66, 346-353. [CrossRef]

96. Sevilla, M.; Fuertes, A.B.; Mokaya, R. High density hydrogen storage in superactivated carbons from hydrothermally carbonized renewable organic materials. Energy Environ. Sci. 2011, 4, 1400-1410. [CrossRef]

97. Deng, J.; Xiong, T.; Xu, F.; Li, M.; Han, C.; Gong, Y.; Wang, H.; Wang, Y. Inspired by bread leavening: One-pot synthesis of hierarchically porous carbon for supercapacitors. Green Chem. 2015, 17, 4053-4060. [CrossRef]

98. Nieva Lobos, M.L.; Manuel Sieben, J.; Comignani, V.; Duarte, M.; Alicia Volpe, M.; Laura Moyano, E. Biochar from pyrolysis of cellulose: An alternative catalyst support for the electro-oxidation of methanol. Int. J. Hydrogen Energy 2016, 41, 10695-10706. [CrossRef]

99. Jagtoyen, M.; Derbyshire, F. Activated carbons from yellow poplar and white oak by H3PO4 activation. Carbon 1998, 36, 1085-1097. [CrossRef]

100. Ucar, S.; Erdem, M.; Tay, T.; Karagoz, S. Preparation and characterization of activated carbon produced from pomegranate seeds by $\mathrm{ZnCl}_{2}$ activation. Appl. Surf. Sci. 2009, 255, 8890-8896. [CrossRef]

101. Sun, L.; Tian, C.; Li, M.; Meng, X.; Wang, L.; Wang, R.; Yin, J.; Fu, H. From coconut shell to porous graphene-like nanosheets for high-power supercapacitors. J. Mater. Chem. A 2013, 1, 6462-6470. [CrossRef]

102. Titirici, M.M.; Thomas, A.; Antonietti, M. Replication and coating of silica templates by hydrothermal carbonization. Adv. Funct. Mater. 2007, 17, 1010-1018. [CrossRef]

103. Titirici, M.M.; Thomas, A.; Antonietti, M. Aminated hydrophilic ordered mesoporous carbons. J. Mater. Chem. 2007, 17, 3412-3418. [CrossRef]

104. Kubo, S.; Tan, I.; White, R.J.; Antonietti, M.; Titirici, M.M. Template synthesis of carbonaceous tubular nanostructures with tunable surface properties. Chem. Mater. 2010, 22, 6590-6597. [CrossRef]

105. White, R.J.; Tauer, K.; Antonietti, M.; Titirici, M.M. Functional hollow carbon nanospheres by latex templating. J. Am. Chem. Soc. 2010, 132, 17360-17363. [CrossRef] [PubMed]

106. Kubo, S.; White, R.J.; Yoshizawa, N.; Antonietti, M.; Titirici, M.M. Ordered carbohydrate-derived porous carbons. Chem. Mater. 2011, 23, 4882-4885. [CrossRef]

107. White, R.J.; Antonietti, M.; Titirici, M.M. Naturally inspired nitrogen doped porous carbon. J. Mater. Chem. 2009, 19, 8645-8650. [CrossRef]

108. Qi, X.; Lian, Y.; Yan, L.; Smith, R.L. One-step preparation of carbonaceous solid acid catalysts by hydrothermal carbonization of glucose for cellulose hydrolysis. Catal. Commun. 2014, 57, 50-54. [CrossRef]

109. Bai, Y.Y.; Xiao, L.P.; Sun, R.C. Microwave-assisted conversion of biomass derived hemicelluloses into xylo-oligosaccharides by novel sulfonated bamboo-based catalysts. Biomass Bioenergy 2015, 75, 245-253. [CrossRef]

110. Guo, H.; Lian, Y.; Yan, L.; Qi, X.; Smith, R.L., Jr. Cellulose-derived superparamagnetic carbonaceous solid acid catalyst for cellulose hydrolysis in an ionic liquid or aqueous reaction system. Green Chem. 2013, 15, 2167-2174. [CrossRef]

111. Liu, Q.Y.; Yang, F.; Sun, X.F.; Liu, Z.H.; Li, G. Preparation of biochar catalyst with saccharide and lignocellulose residues of corncob degradation for corncob hydrolysis into furfural. J. Mater. Cycles Waste Manag. 2017, 19, 134-143. [CrossRef]

112. Ormsby, R.; Kastner, J.R.; Miller, J. Hemicellulose hydrolysis using solid acid catalysts generated from biochar. Catal. Today 2012, 190, 89-97. [CrossRef]

113. Wu, Y.; Fu, Z.; Yin, D.; Xu, Q.; Liu, F.; Lu, C.; Mao, L. Microwave-assisted hydrolysis of crystalline cellulose catalyzed by biomass char sulfonic acids. Green Chem. 2010, 12, 696-700. [CrossRef]

114. Kastner, J.R.; Miller, J.; Geller, D.P.; Locklin, J.; Keith, L.H.; Johnson, T. Catalytic esterification of fatty acids using solid acid catalysts generated from biochar and activated carbon. Catal. Today 2012, 190, 122-132. [CrossRef]

115. Maciá-Agulló, J.A.; Sevilla, M.; Diez, M.A.; Fuertes, A.B. Synthesis of carbon-based solid acid microspheres and their application to the production of biodiesel. ChemSusChem 2010, 3, 1352-1354. [CrossRef] [PubMed]

116. Dehkhoda, A.M.; Ellis, N. Biochar-based catalyst for simultaneous reactions of esterification and transesterification. Catal. Today 2013, 207, 86-92. [CrossRef] 
117. Arneil Arancon, R.; Barros, H.R., Jr.; Balu, A.M.; Vargas, C.; Luque, R. Valorisation of corncob residues to functionalised porous carbonaceous materials for the simultaneous esterification/transesterification of waste oils. Green Chem. 2011, 13, 3162-3167. [CrossRef]

118. Toda, M.; Takagaki, A.; Okamura, M.; Kondo, J.N.; Hayashi, S.; Domen, K.; Hara, M. Green chemistry biodiesel made with sugar catalyst. Nature 2005, 438, 178. [CrossRef] [PubMed]

119. González, M.E.; Cea, M.; Reyes, D.; Romero-Hermoso, L.; Hidalgo, P.; Meier, S.; Benito, N.; Navia, R. Functionalization of biochar derived from lignocellulosic biomass using microwave technology for catalytic application in biodiesel production. Energy Convers. Manag. 2017, 137, 165-173. [CrossRef]

120. Liang, X.; Zeng, M.; Qi, C. One-step synthesis of carbon functionalized with sulfonic acid groups using hydrothermal carbonization. Carbon 2010, 48, 1844-1848. [CrossRef]

121. Shafeeyan, M.S.; Daud, W.M.A.W.; Houshmand, A.; Arami-Niya, A. The application of response surface methodology to optimize the amination of activated carbon for the preparation of carbon dioxide adsorbents. Fuel 2012, 94, 465-472. [CrossRef]

122. Jansen, R.J.J.; van Bekkum, H. Amination and ammoxidation of activated carbons. Carbon 1994, 32, 1507-1516. [CrossRef]

123. Stöhr, B.; Boehm, H.P.; Schlögl, R. Enhancement of the catalytic activity of activated carbons in oxidation reactions by thermal treatment with ammonia or hydrogen cyanide and observation of a superoxide species as a possible intermediate. Carbon 1991, 29,707-720. [CrossRef]

124. Xu, L.; Yao, O.; Zhang, Y.; Fu, Y. Integrated production of aromatic amines and N-doped carbon from lignin via ex situ catalytic fast pyrolysis in the presence of ammonia over zeolites. Energy Convers. Manag. 2017, 5, 2960-2969. [CrossRef]

125. Zhao, L.; Bacsik, Z.; Hedin, N.; Wei, W.; Sun, Y.; Antonietti, M.; Titirici, M.M. Carbon dioxide capture on amine-rich carbonaceous materials derived from glucose. Chemsuschem 2010, 3, 840-845. [CrossRef] [PubMed]

126. Ma, Y.; Liu, W.J.; Zhang, N.; Li, Y.S.; Jiang, H.; Sheng, G.P. Polyethylenimine modified biochar adsorbent for hexavalent chromium removal from the aqueous solution. Bioresource Technol. 2014, 169, 403-408. [CrossRef] [PubMed]

127. Chen, Z.; Ma, L.; Li, S.; Geng, J.; Song, Q.; Liu, J.; Wang, C.; Wang, H.; Li, J.; Qin, Z. Simple approach to carboxyl-rich materials through low-temperature heat treatment of hydrothermal carbon in air. Appl. Surf. Sci. 2011, 257, 8686-8691. [CrossRef]

128. Anfruns, A.; Garcia-Suarez, E.J.; Montes-Moran, M.A.; Gonzalez-Olmos, R.; Martin, M.J. New insights into the influence of activated carbon surface oxygen groups on $\mathrm{H}_{2} \mathrm{O}_{2}$ decomposition and oxidation of pre-adsorbed volatile organic compounds. Carbon 2014, 77, 89-98. [CrossRef]

129. Wu, L.; Sitamraju, S.; Xiao, J.; Liu, B.; Li, Z.; Janik, M.J.; Song, C. Effect of liquid-phase $\mathrm{O}_{3}$ oxidation of activated carbon on the adsorption of thiophene. Chem. Eng. J. 2014, 242, 211-219. [CrossRef]

130. Gokce, Y.; Aktas, Z. Nitric acid modification of activated carbon produced from waste tea and adsorption of methylene blue and phenol. Appl. Surf. Sci. 2014, 313, 352-359. [CrossRef]

131. Li, Y.; Shao, J.; Wang, X.; Deng, Y.; Yang, H.; Chen, H. Characterization of modified biochars derived from bamboo pyrolysis and their utilization for target component (furfural) adsorption. Energy Fuels 2014, 28, 5119-5127. [CrossRef]

132. Luo, W.; Wang, B.; Heron, C.G.; Allen, M.J.; Morre, J.; Maier, C.S.; Stickle, W.F.; Ji, X. Pyrolysis of cellulose under ammonia leads to nitrogen-doped nanoporous carbon generated through methane formation. Nano Lett. 2014, 14, 2225-2229. [CrossRef] [PubMed]

133. Wang, L.; Yan, W.; He, C.; Wen, H.; Cai, Z.; Wanga, Z.X.; Chen, Z.Z.; Liu, W.F. Microwave-assisted preparation of nitrogen-doped biochars by ammonium acetate activation for adsorption of acid red 18. Appl. Surf. Sci. 2018, 433, 222-231. [CrossRef]

134. Nagy, B.; Villar-Rodil, S.; Tascón, J.M.D.; Bakos, I.; László, K. Nitrogen doped mesoporous carbon aerogels and implications for electrocatalytic oxygen reduction reactions. Microporous Mesoporous Mater. 2016, 230, 135-144. [CrossRef]

135. Gao, Y.; Xu, S.P.; Yue, Q.Y.; Ortaboy, S.; Gao, B.Y.; Sun, Y.Y. Synthesis and characterization of heteroatom-enriched biochar from keratin-based and algous-based wastes. Adv. Powder Technol. 2016, 27, 1280-1286. [CrossRef] 
136. Chen, Z.; Li, K.; Pu, L. The performance of phosphorus (p)-doped activated carbon as a catalyst in air-cathode microbial fuel cells. Bioresour. Technol. 2014, 170, 379-384. [CrossRef] [PubMed]

137. Zhu, S.; Huang, X.; Ma, F.; Wang, L.; Duan, X.; Wang, S. Catalytic removal of aqueous contaminants on n-doped graphitic biochars: Inherent roles of adsorption and nonradical mechanisms. Environ. Sci. Technol. 2018. [CrossRef] [PubMed]

138. Zhao, L.; Baccile, N.; Gross, S.; Zhang, Y.; Wei, W.; Sun, Y.; Antonietti, M.; Titirici, M.M. Sustainable nitrogen-doped carbonaceous materials from biomass derivatives. Carbon 2010, 48, 3778-3787. [CrossRef]

139. Guo, Z.; Zhou, Q.; Wu, Z.; Zhang, Z.; Zhang, W.; Zhang, Y.; Li, L.; Cao, Z.; Wang, H.; Gao, Y. Nitrogen-doped carbon based on peptides of hair as electrode materials for surpercapacitors. Electrochim. Acta 2013, 113, 620-627. [CrossRef]

140. Thanh-Dinh, N.; Shopsowitz, K.E.; MacLachlan, M.J. Mesoporous nitrogen-doped carbon from nanocrystalline chitin assemblies. J. Mater. Chem. A 2014, 2, 5915-5921.

141. White, R.J.; Yoshizawa, N.; Antonietti, M.; Titirici, M.-M. A sustainable synthesis of nitrogen-doped carbon aerogels. Green Chem. 2011, 13, 2428-2434. [CrossRef]

142. Baccile, N.; Laurent, G.; Coelho, C.; Babonneau, F.; Zhao, L.; Titirici, M.M. Structural insights on nitrogen-containing hydrothermal carbon using solid-state magic angle spinning $13 \mathrm{C}$ and $15 \mathrm{~N}$ nuclear magnetic resonance. J. Phys. Chem. C 2011, 115, 8976-8982. [CrossRef]

143. Richardson, Y.; Blin, J.; Volle, G.; Motuzas, J.; Julbe, A. In situ generation of ni metal nanoparticles as catalyst for $\mathrm{H}_{2}$-rich syngas production from biomass gasification. Appl. Catal. A 2010, 382, 220-230. [CrossRef]

144. Richardson, Y.; Motuzas, J.; Julbe, A.; Volle, G.; Blin, J. Catalytic investigation of in situ generated ni metal nanoparticles for tar conversion during biomass pyrolysis. J. Phys. Chem. C 2013, 117, 23812-23831. [CrossRef]

145. Shen, Y.; Yoshikawa, K. Tar conversion and vapor upgrading via in situ catalysis using silica-based nickel nanoparticles embedded in rice husk char for biomass pyrolysis/gasification. Ind. Eng. Chem. Res. 2014, 53, 10929-10942. [CrossRef]

146. Shen, Y.; Areeprasert, C.; Prabowo, B.; Takahashi, F.; Yoshikawa, K. Metal nickel nanoparticles in situ generated in rice husk char for catalytic reformation of tar and syngas from biomass pyrolytic gasification. Rsc Adv. 2014, 4, 40651-40664. [CrossRef]

147. Liu, W.J.; Tian, K.; Jiang, H.; Yu, H.Q. Harvest of cu np anchored magnetic carbon materials from fe/cu preloaded biomass: Their pyrolysis, characterization, and catalytic activity on aqueous reduction of 4-nitrophenol. Green Chem. 2014, 16, 4198-4205. [CrossRef]

148. Makowski, P.; Demir Cakan, R.; Antonietti, M.; Goettmann, F.; Titirici, M.M. Selective partial hydrogenation of hydroxy aromatic derivatives with palladium nanoparticles supported on hydrophilic carbon. Chem. Commun. 2008, 999-1001. [CrossRef] [PubMed]

149. Yu, J.C.; Hu, X.; Li, Q.; Zhang, L. Microwave-assisted synthesis and in-situ self-assembly of coaxial Ag/C nanocables. Chem. Commun. 2005, 2704-2706. [CrossRef] [PubMed]

150. Yu, S.H.; Cui, X.J.; Li, L.L.; Li, K.; Yu, B.; Antonietti, M.; Cölfen, H. From starch to metal/carbon hybrid nanostructures: Hydrothermal metal-catalyzed carbonization. Adv. Mater. 2004, 16, 1636-1640. [CrossRef]

151. Liu, W.J.; Tian, K.; Jiang, H.; Zhahg, X.S.; Ding, H.S.; Yu, H.Q. Selectively improving the bio-oil quality by catalytic fast pyrolysis of heavy-metal-polluted biomass: Take copper $(\mathrm{Cu})$ as an example. Environ. Sci. Technol. 2012, 46, 7849-7856. [CrossRef] [PubMed]

152. Zhen, F.; Kaibin, T.; Shuijin, L.; Tanwei, L. CTAB-assisted hydrothermal synthesis of Ag/C nanostructures. Nanotechnology 2006, 17, 3008. [CrossRef]

153. Shen, Y.; Zhao, P.; Shao, Q.; Ma, D.; Takahashi, F.; Yoshikawa, K. In-situ catalytic conversion of tar using rice husk char-supported nickel-iron catalysts for biomass pyrolysis/gasification. Appl. Catal. B-Environ. 2014, 152, 140-151. [CrossRef]

154. Xiaoming, S.; Yadong, L. Colloidal carbon spheres and their core/shell structures with noble-metal nanoparticles. Angew. Chem. Int. Ed. 2004, 43, 597-601.

155. Hu, B.; Zhao, Y.; Zhu, H.Z.; Yu, S.H. Selective chromogenic detection of thiol-containing biomolecules using carbonaceous nanospheres loaded with silver nanoparticles as carrier. ACS Nano 2011, 5, 3166-3171. [CrossRef] [PubMed] 
156. Qian, H.-S.; Antonietti, M.; Yu, S.-H. Hybrid "golden fleece": Synthesis and catalytic performance of uniform carbon nanofibers and silica nanotubes embedded with a high population of noble-metal nanoparticles. Adv. Funct. Mater. 2007, 17, 637-643. [CrossRef]

157. Tang, S.; Vongehr, S.; Meng, X. Carbon spheres with controllable silver nanoparticle doping. J. Phys. Chem. C 2010, 114, 977-982. [CrossRef]

158. Qian, H.S.; Yu, S.H.; Luo, L.B.; Gong, J.Y.; Fei, L.F.; Liu, X.M. Synthesis of uniform te@carbon-rich composite nanocables with photoluminescence properties and carbonaceous nanofibers by the hydrothermal carbonization of glucose. Chem. Mater. 2006, 18, 2102-2108. [CrossRef]

159. Yan, Q.; Lu, Y.; To, F.; Li, Y.; Yu, F. Synthesis of tungsten carbide nanoparticles in biochar matrix as a catalyst for dry reforming of methane to syngas. Catal. Sci. Technol. 2015, 5, 3270-3280. [CrossRef]

160. Zhang, Y.; Wang, A.; Zhang, T. A new 3D mesoporous carbon replicated from commercial silica as a catalyst support for direct conversion of cellulose into ethylene glycol. Chem. Commun. 2010, 46, 862-864. [CrossRef] [PubMed]

161. Wen, L.; Ma, Y.; Dai, B.; Zhou, Y.; Liu, J.; Pei, C. Preparation and dielectric properties of sic nanowires self-sacrificially templated by carbonated bacterial cellulose. Mater. Res. Bull. 2013, 48, 687-690. [CrossRef]

162. Church, T.L.; Fallani, S.; Liu, J.; Zhao, M.; Harris, A.T. Novel biomorphic ni/sic catalysts that enhance cellulose conversion to hydrogen. Catal. Today 2012, 190, 98-106. [CrossRef]

163. Xinyong, T.; Lixin, D.; Xinnan, W.; Wenkui, Z.; Bradley, J.N.; Xiaodong, L.Z. B ${ }_{4}$ C-nanowires/ carbon-microfiber hybrid structures and composites from cotton t-shirts. Adv. Mater. 2010, 22, 2055-2059.

164. Du, J.; Li, Q.; Xia, Y.; Cheng, X.; Gan, Y.; Huang, H.; Zhang, W.; Tao, X. Synthesis of boron carbide nanoflakes via a bamboo-based carbon thermal reduction method. J. Alloys Compd. 2013, 581, 128-132. [CrossRef]

165. Shin, Y.; Li, X.S.; Wang, C.; Coleman, J.R.; Exarhos, G.J. Synthesis of hierarchical titanium carbide from titania-coated cellulose paper. Adv. Mater. 2004, 16, 1212-1215. [CrossRef]

166. Gotoh, Y.; Fujimura, K.; Koike, M.; Ohkoshi, Y.; Nagura, M.; Akamatsu, K.; Deki, S. Synthesis of titanium carbide from a composite of $\mathrm{TiO}_{2}$ nanoparticles/methyl cellulose by carbothermal reduction. Mater. Res. Bull. 2001, 36, 2263-2275. [CrossRef]

167. Li, R.; Shahbazi, A.; Wang, L.; Zhang, B.; Chung, C.C.; Dayton, D.; Yan, Q. Nanostructured molybdenum carbide on biochar for $\mathrm{CO}_{2}$ reforming of $\mathrm{CH}_{4}$. Fuel 2018, 225, 403-410. [CrossRef]

168. Inyang, M.; Gao, B.; Zimmerman, A.; Zhang, M.; Chen, H. Synthesis, characterization, and dye sorption ability of carbon nanotube-biochar nanocomposites. Chem. Eng. J. 2014, 236, 39-46. [CrossRef]

169. Chen, X.W.; Timpe, O.; Hamid, S.B.A.; Schloegl, R.; Su, D.S. Direct synthesis of carbon nanofibers on modified biomass-derived activated carbon. Carbon 2009, 47, 340-343. [CrossRef]

170. Baker, R.T.K. Catalytic growth of carbon filaments. Carbon 1989, 27, 315-323. [CrossRef]

171. Chen, S.; Rotaru, A.E.; Shrestha, P.M.; Malvankar, N.S.; Liu, F.; Fan, W.; Nevin, K.P.; Lovley, D.R. Promoting interspecies electron transfer with biochar. Sci. Rep. 2014, 4. [CrossRef] [PubMed]

172. Konwar, L.J.; Boro, J.; Deka, D. Review on latest developments in biodiesel production using carbon-based catalysts. Renew. Sustain. Energy Rev. 2014, 29, 546-564. [CrossRef]

173. Wang, S.; Zhao, C.; Shan, R.; Wang, Y.; Yuan, H. A novel peat biochar supported catalyst for the transesterification reaction. Energy Convers. Manag. 2017, 139, 89-96. [CrossRef]

174. Atadashi, I.M.; Aroua, M.K.; Abdul Aziz, A.R.; Sulaiman, N.M.N. The effects of catalysts in biodiesel production: A review. J. Ind. Eng. Chem. 2013, 19, 14-26. [CrossRef]

175. Melero, J.A.; Iglesias, J.; Morales, G. Heterogeneous acid catalysts for biodiesel production: Current status and future challenges. Green Chem. 2009, 11, 1285-1308. [CrossRef]

176. Li, M.; Zheng, Y.; Chen, Y.; Zhu, X. Biodiesel production from waste cooking oil using a heterogeneous catalyst from pyrolyzed rice husk. Bioresour. Technol. 2014, 154, 345-348. [CrossRef] [PubMed]

177. Lee, J.; Jung, J.M.; Oh, J.I.; Ok, Y.S.; Lee, S.R.; Kwon, E.E. Evaluating the effectiveness of various biochars as porous media for biodiesel synthesis via pseudo-catalytic transesterification. Bioresour. Technol. 2017, 231, 59-64. [CrossRef] [PubMed]

178. Zeng, D.; Liu, S.; Gong, W.; Wang, G.; Qiu, J.; Chen, H. Synthesis, characterization and acid catalysis of solid acid from peanut shell. Appl. Catal. A 2014, 469, 284-289. [CrossRef]

179. Yu, J.T.; Dehkhoda, A.M.; Ellis, N. Development of biochar-based catalyst for transesterification of canola oil. Energy Fuels 2011, 25, 337-344. [CrossRef] 
180. Chen, S.S.; Maneerung, T.; Tsang, D.C.W.; Ok, Y.S.; Wang, C.H. Valorization of biomass to hydroxymethylfurfural, levulinic acid, and fatty acid methyl ester by heterogeneous catalysts. Chem. Eng. J. 2017, 328, 246-273. [CrossRef]

181. Shu, Q.; Gao, J.; Nawaz, Z.; Liao, Y.; Wang, D.; Wang, J. Synthesis of biodiesel from waste vegetable oil with large amounts of free fatty acids using a carbon-based solid acid catalyst. Appl. Energy 2010, 87, 2589-2596. [CrossRef]

182. Dawodu, F.A.; Ayodele, O.; Xin, J.; Zhang, S.; Yan, D. Effective conversion of non-edible oil with high free fatty acid into biodiesel by sulphonated carbon catalyst. Appl. Energy 2014, 114, 819-826. [CrossRef]

183. Endut, A.; Abdullah, S.H.Y.S.; Hanapi, N.H.M.; Hamid, S.H.A.; Lananan, F.; Kamarudin, M.K.A.; Umar, R.; Juahir, H.; Khatoon, H. Optimization of biodiesel production by solid acid catalyst derived from coconut shell via response surface methodology. Int. Biodeterior. Biodegrad. 2017, 124, 250-257. [CrossRef]

184. Xiangcheng, L.; Kaihao, P.; Xiaohui, L.; Qineng, X.; Yanqin, W. Comprehensive understanding of the role of brønsted and lewis acid sites in glucose conversion into 5-hydromethylfurfural. ChemCatChem 2017, 9, 2739-2746.

185. Gallo, J.M.R.; Alamillo, R.; Dumesic, J.A. Acid-functionalized mesoporous carbons for the continuous production of 5-hydroxymethylfurfural. J. Mol. Catal. A: Chem. 2016, 422, 13-17. [CrossRef]

186. Bazargan, A.; Kostić, M.D.; Stamenković, O.S.; Veljković, V.B.; McKay, G. A calcium oxide-based catalyst derived from palm kernel shell gasification residues for biodiesel production. Fuel 2015, 150, 519-525. [CrossRef]

187. Kostić, M.D.; Bazargan, A.; Stamenković, O.S.; Veljković, V.B.; McKay, G. Optimization and kinetics of sunflower oil methanolysis catalyzed by calcium oxide-based catalyst derived from palm kernel shell biochar. Fuel 2016, 163, 304-313. [CrossRef]

188. Chakraborty, R.; Bepari, S.; Banerjee, A. Transesterification of soybean oil catalyzed by fly ash and egg shell derived solid catalysts. Chem. Eng. J. 2010, 165, 798-805. [CrossRef]

189. Smith, S.M.; Oopathum, C.; Weeramongkhonlert, V.; Smith, C.B.; Chaveanghong, S.; Ketwong, P.; Boonyuen, S. Transesterification of soybean oil using bovine bone waste as new catalyst. Bioresour. Technol. 2013, 143, 686-690. [CrossRef] [PubMed]

190. Madhu, D.; Chavan, S.B.; Singh, V.; Singh, B.; Sharma, Y.C. An economically viable synthesis of biodiesel from a crude millettia pinnata oil of jharkhand, india as feedstock and crab shell derived catalyst. Bioresour. Technol. 2016, 214, 210-217. [CrossRef] [PubMed]

191. Dhawane, S.H.; Kumar, T.; Halder, G. Central composite design approach towards optimization of flamboyant pods derived steam activated carbon for its use as heterogeneous catalyst in transesterification of hevea brasiliensis oil. Energy Convers. Manag. 2015, 100, 277-287. [CrossRef]

192. Jung, J.M.; Oh, J.I.; Baek, K.; Lee, J.; Kwon, E.E. Biodiesel production from waste cooking oil using biochar derived from chicken manure as a porous media and catalyst. Energy Convers. Manag. 2018, 165, 628-633. [CrossRef]

193. Wang, S.; Yuan, H.; Wang, Y.; Shan, R. Transesterification of vegetable oil on low cost and efficient meat and bone meal biochar catalysts. Energy Convers. Manag. 2017, 150, 214-221. [CrossRef]

194. Tuck, C.O.; Perez, E.; Horvath, I.T.; Sheldon, R.A.; Poliakoff, M. Valorization of biomass: Deriving more value from waste. Science 2012, 337, 695-699. [CrossRef] [PubMed]

195. Wataniyakul, P.; Boonnoun, P.; Quitain, A.T.; Sasaki, M.; Kida, T.; Laosiripojana, N.; Shotipruk, A. Preparation of hydrothermal carbon as catalyst support for conversion of biomass to 5-hydroxymethylfurfural. Catal. Commun. 2018, 104, 41-47. [CrossRef]

196. Zhou, C.H.; Xia, X.; Lin, C.X.; Tong, D.S.; Beltramini, J. Catalytic conversion of lignocellulosic biomass to fine chemicals and fuels. Chem. Soc. Rev. 2011, 40, 5588-5617. [CrossRef] [PubMed]

197. Zhang, X.; Wilson, K.; Lee, A.F. Heterogeneously catalyzed hydrothermal processing of C5-C6 sugars. Chem. Rev. 2016, 116, 12328-12368. [CrossRef] [PubMed]

198. Deng, A.; Lin, Q.; Yan, Y.; Li, H.; Ren, J.; Liu, C.; Sun, R. A feasible process for furfural production from the pre-hydrolysis liquor of corncob via biochar catalysts in a new biphasic system. Bioresour. Technol. 2016, 216, 754-760. [CrossRef] [PubMed]

199. Jiang, Y.; Li, X.; Wang, X.; Meng, L.; Wang, H.; Peng, G.; Wang, X.; Mu, X. Effective saccharification of lignocellulosic biomass over hydrolysis residue derived solid acid under microwave irradiation. Green Chem. 2012, 14, 2162-2167. [CrossRef] 
200. Okamura, M.; Takagaki, A.; Toda, M.; Kondo, J.N.; Domen, K.; Tatsumi, T.; Hara, M.; Hayashi, S. Acid-catalyzed reactions on flexible polycyclic aromatic carbon in amorphous carbon. Chem. Mater. 2006, 18, 3039-3045. [CrossRef]

201. Shen, Y.; Chen, M.; Sun, T.; Jia, J. Catalytic reforming of pyrolysis tar over metallic nickel nanoparticles embedded in pyrochar. Fuel 2015, 159, 570-579. [CrossRef]

202. Wang, D.; Yuan, W.; Ji, W. Char and char-supported nickel catalysts for secondary syngas cleanup and conditioning. Appl. Energy 2011, 88, 1656-1663. [CrossRef]

203. Bhandari, P.N.; Kumar, A.; Huhnke, R.L. Simultaneous removal of toluene (model tar), $\mathrm{NH}_{3}$, and $\mathrm{H}_{2} \mathrm{~S}$, from biomass-generated producer gas using biochar-based and mixed-metal oxide catalysts. Energy Fuels 2014, 28, 1918-1925. [CrossRef]

204. Mani, S.; Kastner, J.R.; Juneja, A. Catalytic decomposition of toluene using a biomass derived catalyst. Fuel Process. Technol. 2013, 114, 118-125. [CrossRef]

205. Feng, D.; Zhao, Y.; Zhang, Y.; Sun, S. Effects of $\mathrm{H}_{2} \mathrm{O}$ and $\mathrm{CO}_{2}$ on the homogeneous conversion and heterogeneous reforming of biomass tar over biochar. Int. J. Hydrogen Energy 2017, 42, 13070-13084. [CrossRef]

206. Kastner, J.R.; Mani, S.; Juneja, A. Catalytic decomposition of tar using iron supported biochar. Fuel Process. Technol. 2015, 130, 31-37. [CrossRef]

(C) 2018 by the authors. Licensee MDPI, Basel, Switzerland. This article is an open access article distributed under the terms and conditions of the Creative Commons Attribution (CC BY) license (http://creativecommons.org/licenses/by/4.0/). 